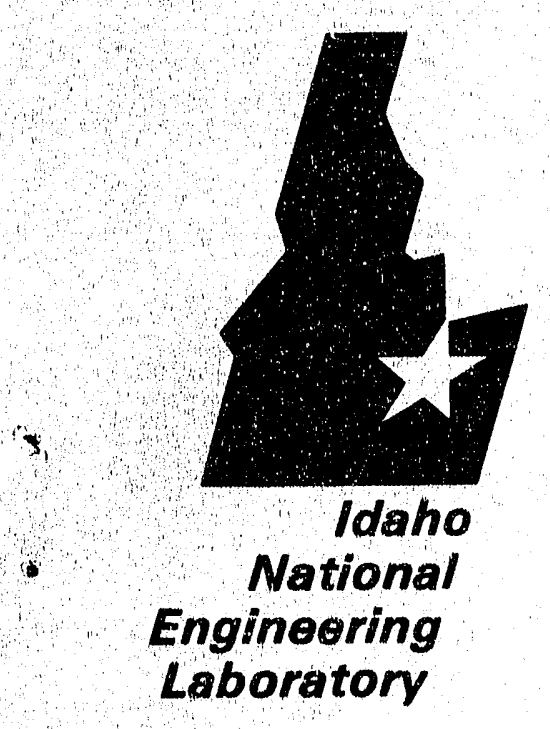

Managed

by the U.S.

Department

of Energy $\ln 562 a_{\text {dano }}$

Work performed under DOE Contract No. DE-AC07.761D01570
EGG-WTD-9993

January 1992
APR:'?, 1992

\section{Energy \& Costs Scoping Study for Plasma Pyrolysis Thermal Processing System}

\author{
K. E. Sherick \\ J. E. Findley
}


This document contains new concepts or the author(s) interpretation of new calculations and/or measurements; accordingly, EG\&G Idaho, Inc. is required by the United States Government to include the following disclaimer:

\section{DISCLAIMER}

This report was prepared as an account of work sponsored by an agency of the United States Government. Neither the United States Government nor any agency thereof, nor any of their employees, makes any warranty, express or implied, or assumes any legal liability or responsibility for the accuracy, completeness, or usefulness of any information, apparatus, product or process disclosed, or represents that its use would not infringe privately owned rights. References herein to any specific commercial product, process, or service by trade name, trademark, manulacturer, or otherwise, does not necessarily constitute or imply its endorsement, recommendation, or favoring by the United States Government or any agency thereot. The views and opinions of authors expressed herein do not necessarily state or reflect those of the United States Government or any agency thereof. 


\section{Energy \& Costs Scoping Study for Plasma Pyrolysis Thermal Processing System}

K. E. Sherick

J. E. Findley

January 1992

\section{Idaho National Engineering Laboratory EG\&G Idaho, Inc. Idaho Falls, Idaho 83415}

Prepared for

Office of Environmental Restoration and Waste Management U.S. Department of Energy Under DOE Idaho Fleld Offlce Contract DE-AC07-76ID01570 
Energy \& Costs Scoping Study for Plasma Pyrolysis Thermal Processing System

Prepared by:
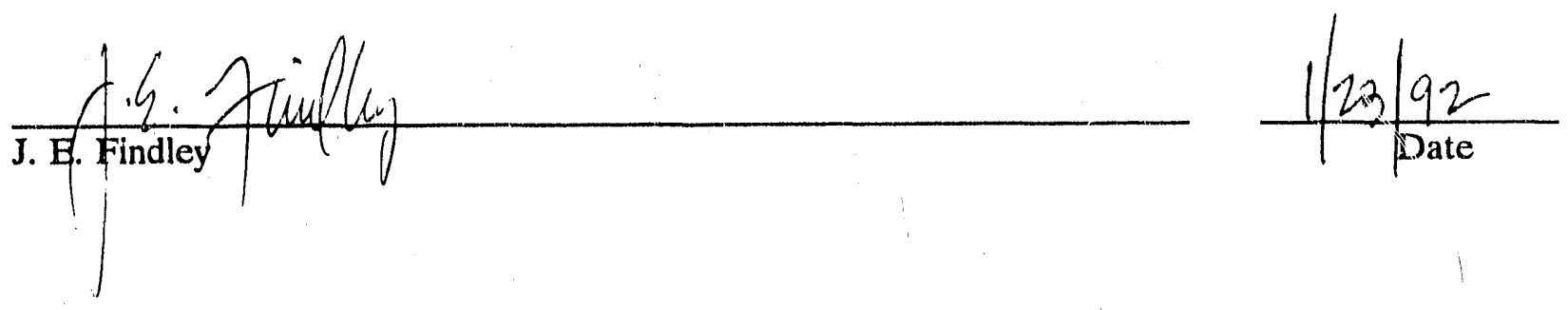

Approved by:
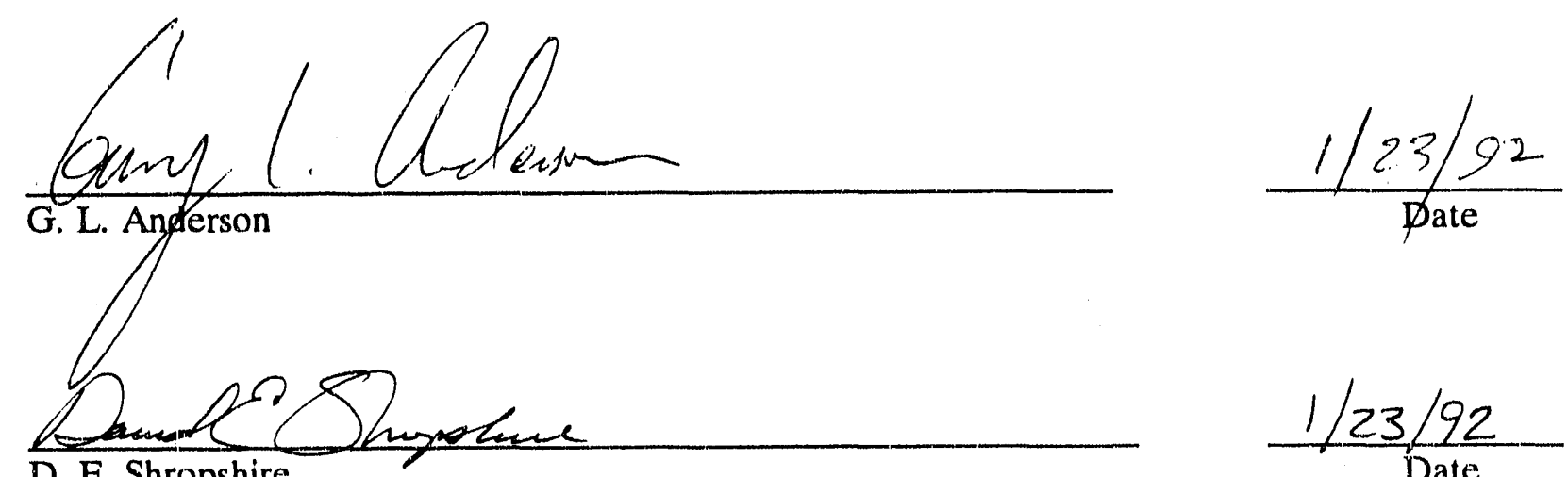

D. E. Shropshire

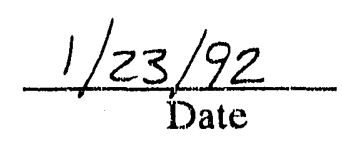




\begin{abstract}
The purpose of this study was to provide information in support of an investigation of thermal technologies as possible treatment process for buried wastes at the INEL. Material and energy balances and a cost estimate were generated for a representative plasma torch-based thermal waste treatment system operating in a pyrolysis mode. Two waste streams were selected which are representative of INEL buried wastes, large in volume, and difficult to treat by other technologies. These streams were a solidified nitrate sludge waste stream and a waste/soil mix of other buried waste components. The treatment scheme selected includes a main plasma chamber operating under pyrolyzing conditions; a plasma afterburner to provide additional residence time at high temperature to ensure complete destruction of hazardous organics; an off-gas treatment system; and an incinerator and stack to oxidize carbon monoxide to carbon clioxide and vent the clean, oxidized gases to atmosphere. The material balances generated provide materials flow and equipment duty information of sufficient accuracy to generate initial rough-order-of-magnitude (ROM) system capital and operating cost estimates for a representative plasma thermal processing system.
\end{abstract}




\section{EXECUTIVE SUMMARY}

The purpose of this study was to provide information in support of an investigation of thermal systems technology as a possible treatment process for buried wastes at the Idaho National Engineering Laboratory (INEL). Material and energy balances and a cost estimate were generated for a representative plasma torch-based thermal waste treatment system operating in a pyrolysis mode. These balances provide materials flow and equipment duty information of sufficient accuracy to generate initial ROM system capital and operating cost estimates for a representative plasma thermal processing system.

Although this study was based upon system conditions expected to be achieved in a plasma torch-based waste treatment system operating in a pyrolysis mode, the overall mass flows, and calculated energy requirements are expected to be $:$ :OM representative of any full-scale plasma (electric furnace) pyrolysis waste treatment system for the typical waste streams chosen. The chemical reactions, mass flows, and energy balances are largely determined by the composition of the waste streams chosen, which in turn drives the system component types, sizes, and costs.

For a given waste stream and throughput, the factors that would have the most significant influence on capital and operating costs for a plasma-based system are: operation of the main plasma chamber under oxidizing versus pyrolyzing conditions; use of oxygen versus air to oxidize organics; and the extent to which waste heat is recovered. Operation of the main plasma chamber under oxidizing conditions increases the volume of off-gas, and thus the size of the off-gas treatment equipment, but reduces the power input to the plasma torch due to the heat provided by combustion of the organics. Use of oxygen versus air to oxidize organics will also reduce off-gas volume at the expense of the costs to generate oxygen. Waste heat recovery will reduce operating costs, if the waste energy can be used, at the expense of capital cost.

The thermal processing scheme selected for this study was chosen based on the results of ongoing and previous thermal plasma processing system technology studies and on input from current vendors of plasma torch-based thermal processing equipment. The scheme selected includes a main plasma chamber operating under pyrolyzing conditions, a plasma afterburner to provide additional residence time at high temperature to ensure complete destruction of hazardous organics, an off-gas treatment system, and an incinerator and stack to oxidize carbon monoxide to carbon dioxide and vent the clean, oxidized gases to the atmosphere. The off-gas treatment subsystem configuration used in this study was patterned after the off-gas treatment subsystem utilized for in situ vitrification process systems as designed by Pacific Northwest Laboratories (PNL). Technical and economic trade-off studies to optimize the process were not included as part of this study. Additional work would be needed to determine the influence of variations in system components and key performance assumptions.

Two waste streams were selected that are representative of INEL buried wastes, large in volume, and difficult to treat by other technologies. These streams were a solidified nitrate sludge 
waste stream and a waste/soil mix of other buried waste components. The wastes throughput (flow rate) used was based on the largest commercial design capacity for a plasma pyrolysis-based system. for processing municipal solid waste. This system has not been built or operated.

A combination of manual calculations and commercial process simulation codes was used to generate the material and energy balances. The calculational approach and methods used in this study are focused upon determination of bulk mass and energy balances and are not sufficiently rigorous to determine the distribution of trace species [e.g. transuranic (TRU)] throughout the process. Bulk vapor and liquid phase temperatures expected to exist in the main plasma chamber were key assumptions and are based upon typical values obtained from experienced system vendors. The distribution of species between the vapor and liquid phases in the main chamber was determined based on the vapor pressure of each species at the vapor phase conditions (assumed temperature). It was further assumed that there were no chemical reactions between liquid phase species, that there was no entrainment of liquid or solids into the vapor phase, and that the vapor phase species were in chemical equilibrium at the vapor phase conditions (assumed temperature). Appendix D provides further explanation.

Resulting material and energy balances for the two waste streams selected for this study are discussed further in Section 5 and included in Appendix A. The ROM total estimated cost for the plasma system selected is $\$ 21.8$ (December 1991 dollars). The bases and key assumptions for this cost estimate are discussed in detail in Appendix C.

The focus of this study was upon providing a first cut scoping estimate of energy requirements and costs for a single representative plasma thermal processing system. There are numerous system and component variations possible within this system and other systems technology-based thermal processing systems that deserve further study. The approach and methods used in this study may be used to prepare material and en rgy balances and cost estimales for other thermal treatment systems and for other waste streams. Further studies of this type are required for comparing ROM capital costs, utility requirements, and operating cost: of other likely thermal processing systems. 


\section{ACKNOWLEDGEMENTS}

This report was prepared for the Waste Technology Development Department of EG\&G Idaho, Inc., under contract to the U.S. Department of Energy Idaho Field Office, Office of Technology Development. Funding was provided under FY-91 Thermal Processing Technologies Technical Task Plans ID-0502-DT, 1991, and ID-040E-2D, 1992. 


\section{CONTENTS}

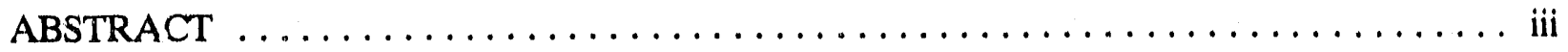

EXECUTIVE SUMMARY $\ldots \ldots \ldots \ldots \ldots \ldots \ldots \ldots \ldots \ldots \ldots \ldots \ldots \ldots$

ACKNOWLEDGEMEN $\Gamma$ S $\ldots \ldots \ldots \ldots \ldots \ldots \ldots \ldots \ldots \ldots \ldots \ldots \ldots$ vii

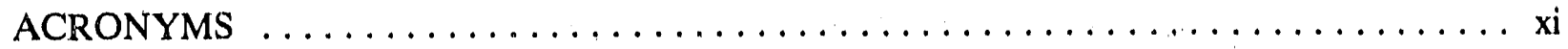

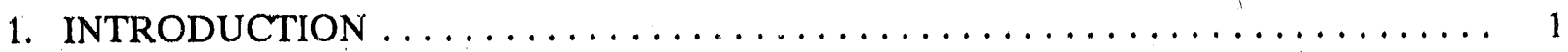

2. PLASMA TECHNOLOGY DESCRIPTION $\ldots \ldots \ldots \ldots \ldots \ldots \ldots \ldots \ldots$

3. FEED STREAMS $\ldots \ldots \ldots \ldots \ldots \ldots \ldots \ldots \ldots \ldots \ldots \ldots \ldots \ldots \ldots \ldots$

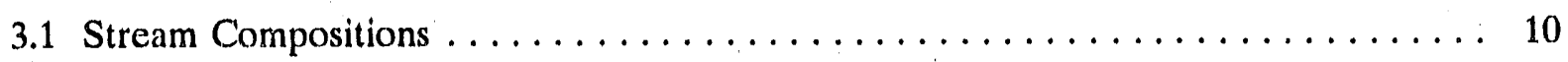

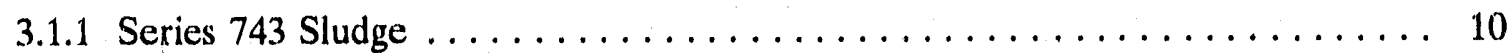

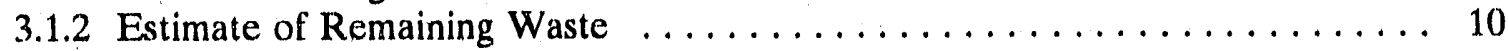

4. PROCESS CONFIGURATION $\ldots \ldots \ldots \ldots \ldots \ldots \ldots \ldots \ldots \ldots \ldots \ldots \ldots$

4.1 Main Plasma Chamber ........................... 14

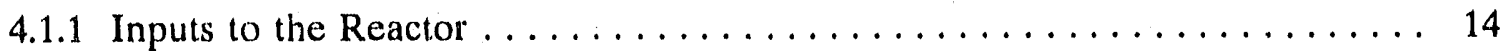

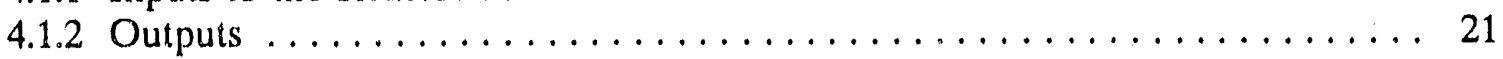

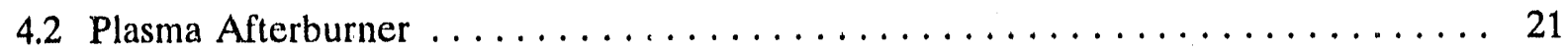

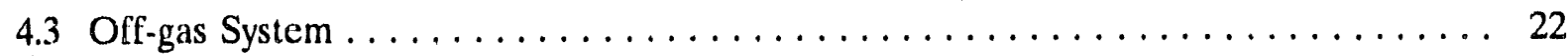

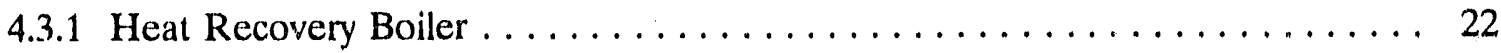

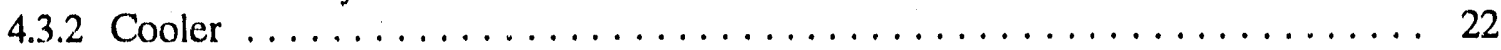

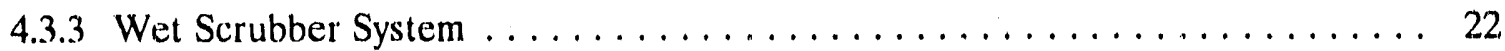

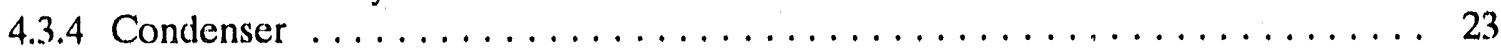

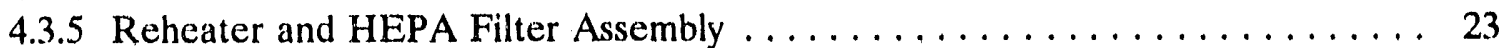

4.3.6 Blower .................................. 23

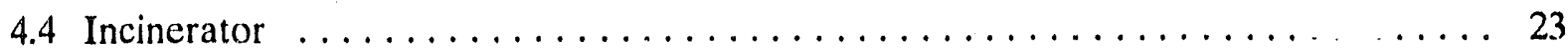

5. MASS AND ENERGY BALANCES $\ldots \ldots \ldots \ldots \ldots \ldots \ldots \ldots \ldots \ldots \ldots \ldots$

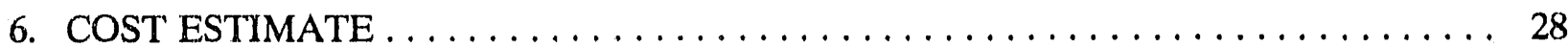

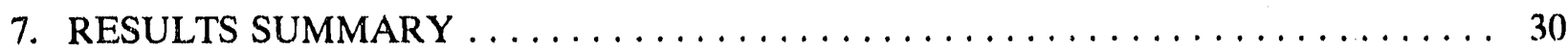

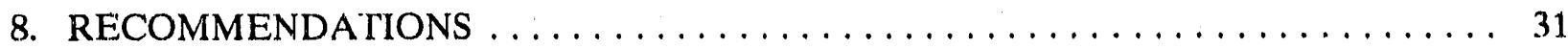


APPENDIX A-MASS BALANCE TABLES $\ldots \ldots \ldots \ldots \ldots \ldots \ldots \ldots \ldots \ldots \ldots$

APPENDIX B--SUMMARY OF ENERGY BALANCE CALC $J L A T I O N S \ldots \ldots \ldots \ldots$ B-1

APPENDIX C-.COST ESTIMATE $\ldots \ldots \ldots \ldots \ldots \ldots \ldots \ldots \ldots \ldots \ldots \ldots \ldots \ldots$

APPENDIX D-DISCUSSION OF CALCULATION METHODS $\ldots \ldots \ldots \ldots \ldots \ldots$. $\ldots \ldots$

FIGURES

1. Process Flow Diagram $\ldots \ldots \ldots \ldots \ldots \ldots \ldots \ldots \ldots \ldots \ldots \ldots \ldots \ldots \ldots$

2. Plasma Refuse Converter from Plasma Energy Corporation $\ldots \ldots \ldots \ldots \ldots \ldots \ldots$

\section{TABLES}

1. Estimated amounts of buried waste contributed by various sources $\ldots \ldots \ldots \ldots$

2. Compositional breakdown of Stream $1 \ldots \ldots \ldots \ldots \ldots \ldots \ldots \ldots \ldots \ldots \ldots$

3. Compositional breakdown of Stream $2 \ldots \ldots \ldots \ldots \ldots \ldots \ldots \ldots \ldots \ldots \ldots \ldots$

4. Compositional feed rates of Stream 1 into Plasma Reactor $\ldots \ldots \ldots \ldots \ldots \ldots$

5. Compositional Feed Rates of Stream 2 into Plasma Reactor . . . . . . . . . . . 19

6. Mass and energy summary for treatment of Stream 1 (Sludges) $\ldots \ldots \ldots \ldots \ldots$

7. Mass and energy summary for treatment of Stream $2 \ldots \ldots \ldots \ldots \ldots \ldots$ 


\section{ACRONYMS}

ANL

ARA

CFA

DC

GCRE

HEPA

ICPP

INEL

$\mathrm{kgmoles} / \mathrm{hr}$

MW

NASA

NEPA

NRF

OMRE

PEC

PNL

PRC

psi

psig

RFP

ROM

RWMC

SDA

SPERT
Argonne National Laboratory

Auxillary Reactor Area

Central Facilities Area

direct current

gas-cooled reactor experiment

high efficiency particulate air (filter)

Idaho Chemical Processing Plant

Idaho National Engineering Laboratory

kilogram-moles per hour

megawatt

National Aeronautics and Space Administration

National Environmental Policy Act

Naval Reactor Facility

organic-moderated reactor experiment

Plasma Energy Corporation

Pacific Northwest Laboratory

plasma refuse converter

pounds per square inch

pounds per square inch (gauge)

Rocky Flats Plant

rough-order-of-magnitude

Radioactive Waste Management Complex

Subsurface Disposal Area

Special Power Excursion Reactor Test 
T'AN

TRA

TRU

WERF

WIPP
Test Area North

Test Reactor Area

transuranic

Waste Experimental Reduction Facility

Waste Isolation Pilot Plant 


\section{Energy \& Costs Scoping Study for Plasma Pyrolysis Thermal Processing System}

\section{INTRODUCTION}

The main purpose of the this study was to provide information in support of an investigation of thermal processing systems technology as a possible treatment process for buried waste at the INEL. In particular, the scope of this project was to provide a ROM estimate of the energy requirements and costs for a representative plasma torch-based waste processing system. The estimate was to be basicd upon the results of the following tasks:

- $\quad$ Choose two appropriate waste streams for plasma processing. The streams should be representative of INEL buried waste, large in volume, difficult to treat by other technologies, and identified as hazardous and radioactive.

- Based upon review of ongoing and previous studies of thermal treatment technologies and input from appropriate commercial technology suppliers, select a plasma waste treatment scheme.

- Calculate material and energy balances for the selected plasma system, generate a conceptual process flow diagram, and prepare a scoping cost estimate.

The waste streams were chosen from the Plasma Candidate Waste Stream Survey. ${ }^{1}$ Other hazardous constituents were added to obtain more representative data for mass and energy balances. ${ }^{8}$ The main plasma chamber and the plasma afterburner systems evaluated in this study are based on a 125 ton/day Plasma Refuse Converter design by Plasma Energy Corporation (PEC) and a plasma afterburner design by Scorpion Manufacturing respectively. These designs were chosen based upon each company's research and testing experience in plasma processes.

The off-gas system chosen for this study is similar to Pacific Northwest Laboratory's off-gas system utilized for in situ vitrification processing tests. It is an established system that can handle radionuclides, particulates, and acid gases. To minimize the size and cost of the off-gas system, it was assumed in this study that the final exhaust gases will be incinerated downstream of the off-gas system as necessary. The purpose of the final incineration step is to oxidize carbon monoxide to carbon dioxide. The stack gas effluent will consist of simple, nonhazardous molecules such as carbon dioxide, 
nitrogen, and water. These gases will then be vented to the atmosphere."'A crystalline slag is produced by the plasma furnace which upon cooling immobilizes radionuclides, heavy metals, and other inorganics into a essentially nonleachable ceramic form suitable for long-term storage or final disposal. 


\section{PLASMA TECHNOLOGY DESCRIPTION}

Thermal plasma processing utilizes a plasma torch or arc to treat solid and liquid waste at very high temperatures to destroy the toxic organic materials and to stabilize the inorganics by forming a vitrified ceramic product that is essentially nonleachable. Thermal plasma processing technology is a promising technique for processing hazardous and mixed wastes and is being evaluated as a potential treatment process for INEL buried waste. It is anticipated that plasma torch or arc processing can successfully treat hazardous, low-level, transuranic, and mixed waste to meet final disposal requirements. The technology is considered excellent for radioactive alpha contamination control during processing, because of the potential for having a sealed reaction vessel.

A plasma is created when gas is ionized by heating it with a high-power dc electric arc strong enough to strip electrons from the gas molecules. When hazardous wastes are directly subjected to the high levels of energy delivered by the plasma, the molecular siructure of the waste components are broken down into their atomic constituents. Only a small amount of gas is required to create this high-temperature plasma resulting in a smaller off-gas system compared to conventional incineration. When plasma is used to heat inert materials, such as soil to form a molten bath, a very uniform, hightemperature environment can be created. The temperature of the bath is high enough to ensure thermal destruction of the organic wastes even though the temperatures of the molten bath are far below the actual plasma temperatures. Heavy metal contaminants are dissolved in the molten slag/bath. Upon cooling, an essentially nonleachable solid results which requires no further treatment. If enough energy is supplied through the plasma torch, the process should be able to treat waste with any physical characteristic, including unopened waste-filled drums. ${ }^{2}$ The resultant slag characteristics are currently being studied by several companies, one of which is MSE, Inc. in Butte, Montana, who is involved in the Plasma Arc Furnace Experiment (the Plasma Centrifugal Reactor configuration by Retech). 


\section{FEED STREAMS}

The main criteria for selecting the candidate waste feed streams for this study was that the streams reflect the actual waste that may be treated by thermal plasma processing at the INEL.- This could have been accomplished by selecting a "best" and "worst" case stream, or by selection of representative streams. However, bracketing the study with a best and worst case stream would have required the development of a set of criteria and a rigorous application of these criteria. Due to time limitations and limited information on actual waste characteristics, it was decided that representative streams would be more appropriate for this scoping study.

The initial step in the selection process was to concentrate efforts on only one of the four broad categories of waste found at the INEL. The four broad categories considered were stored waste, buried waste, mixed waste, and waste currently generated. Stored waste comprises a large volume of the waste at the INEL and is relatively well characterized. However, stored waste is scheduled for shipment to the Waste Isolation Pilot Plant (WIPP) and the need for processing the stored waste is not urgent. The mixed waste is a serious concern for regulatory reasons, but the small quantities of mixed waste currently at the Radioactive Mixed Waste Storage Facility (RMWSF) will not likely justify the design of a new process. Waste currently being generated amounts to relatively small quantities and much of it is treated at the Waste Experimental Reduction Facility (WERF). The buried waste is not well characterized and there are extremely large quantities of buried waste. Furthermore, there is a great deal of public concern about migration of radioactive and hazardous constituents from buried waste sites. For these reasons, it was decided that the representative waste streams would come from the buried waste.

Table 1 is a summary of buried waste streams contributed by various sources. ${ }^{1}$ The first step in the selection process was to eliminate any streams with $<1000 \mathrm{~m}^{3}$ of waste. This is a somewhat arbitrary criteria, but the idea was to concentrate on the larger volume streams. The next step in the selection process was to eliminate any of the streams that did not have adequate available descriptions, or would not be considered hazardous waste. The remaining streams consisted primarily of the Rocky Flats Plant (RFP) sludges (excluding Series 744 Sludge) and various general waste streams ("general" means that the streams contained a variety of waste forms).

It was decided that a sludge wculd be a good candidate for treatment for several reasons. Most conventional technologies would only be marginally effective when applied to the cemented or solidified sludges. Furthermore, the $74 \mathrm{X}$ series sludges constitute a large portion of the RFP buried waste. It was decided to concentrate efforts on the Series 743 sludge since it has been characterized more extensively than some of the other sludges and has the highest percentage of hazardous organics. 


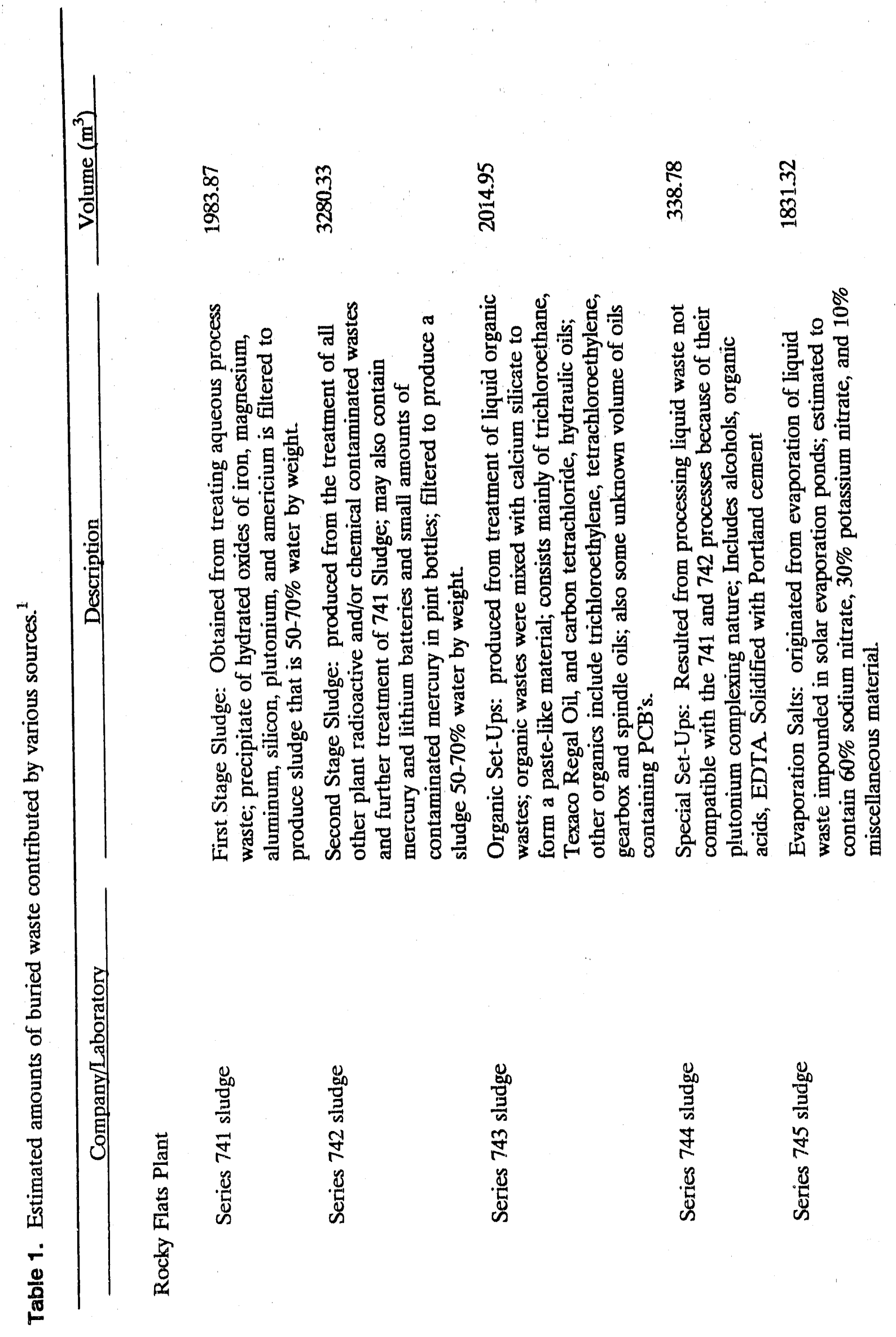




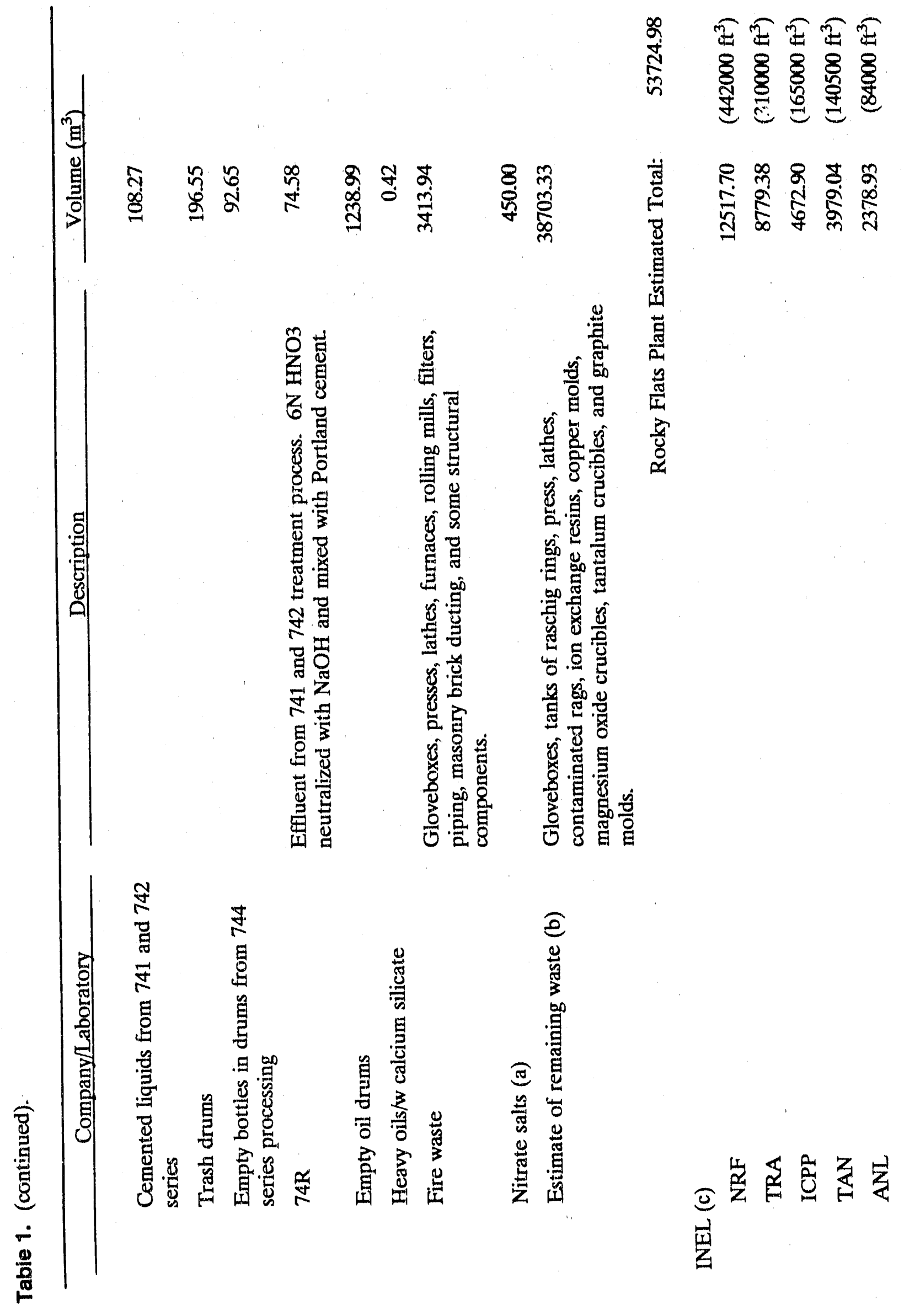




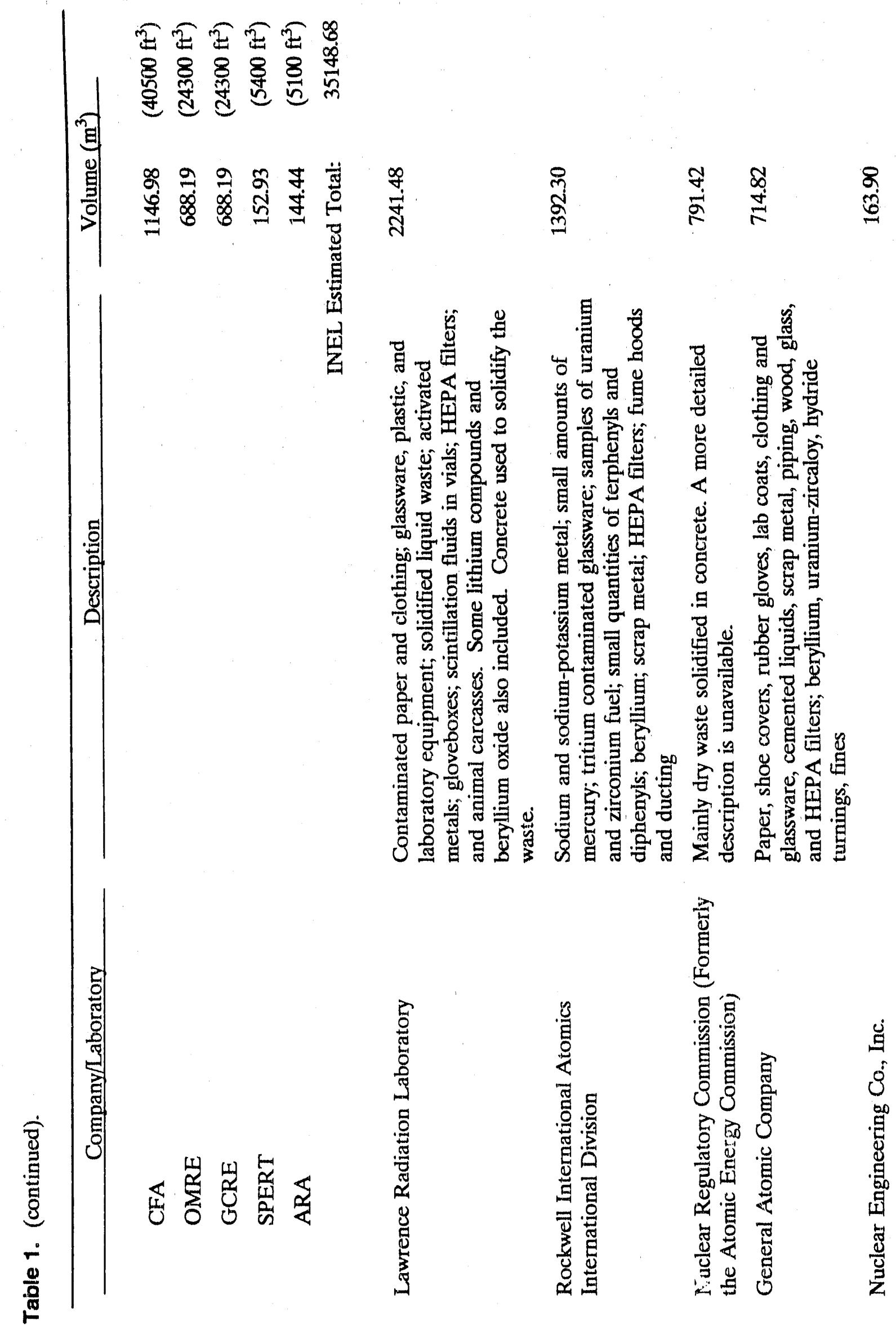




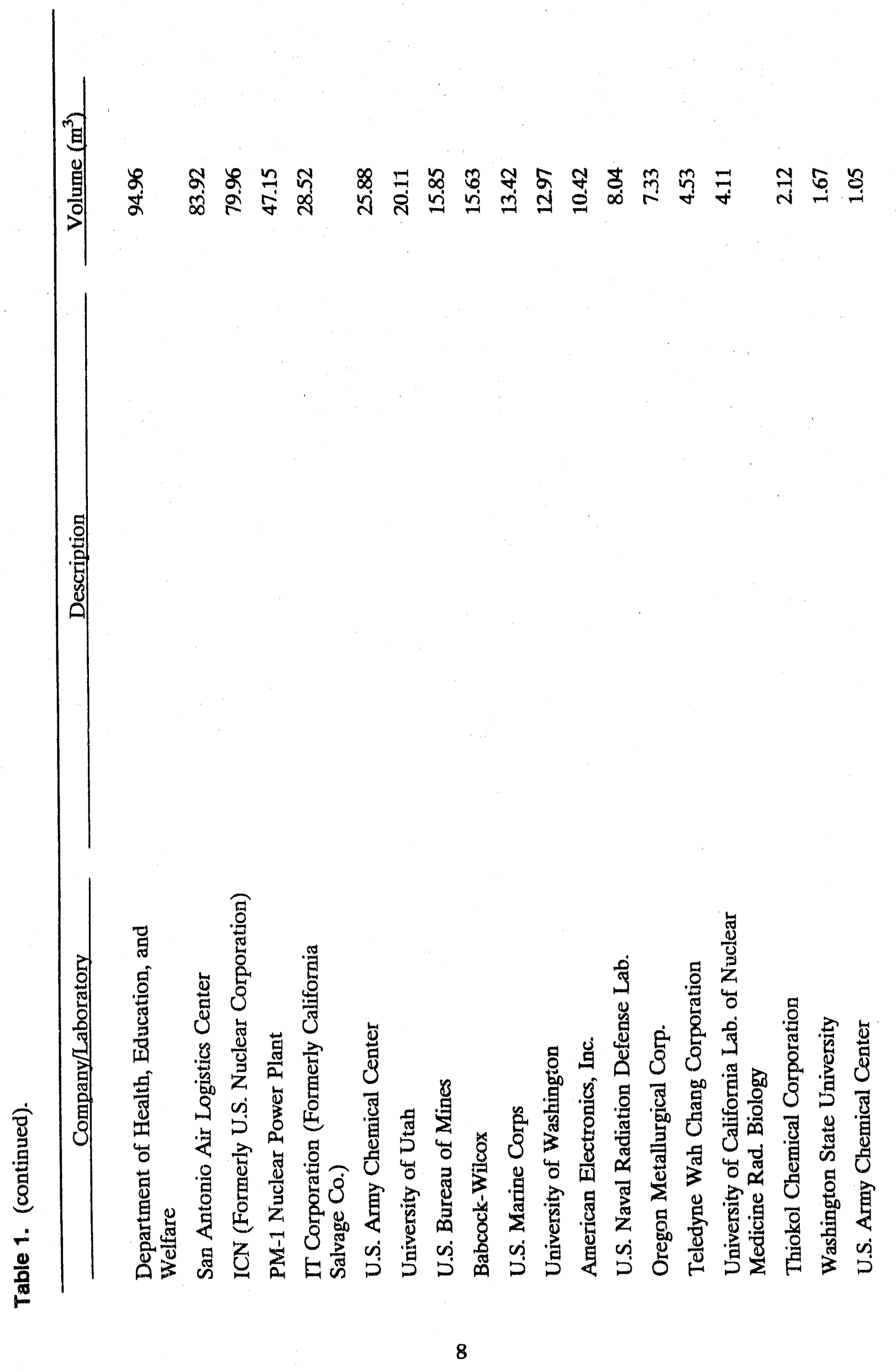




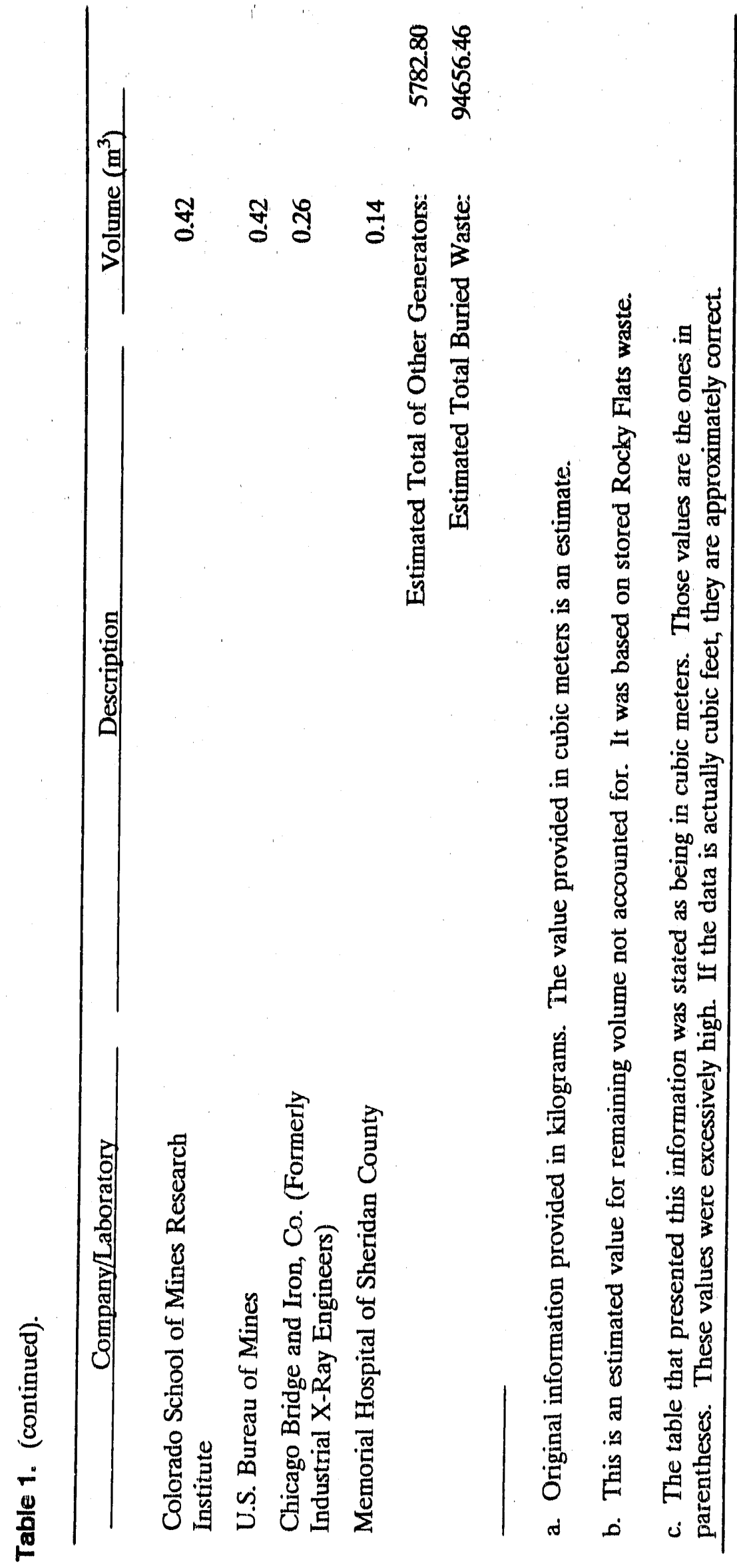


The other stream that was selected was the stream referred to as "Estimate of Remaining Waste." This stream contains essentially all of the RFP waste outside of sludges and fire waste. The mixture of metals, glass, plastics, cloth, paper, soil, and other miscellaneous items would present serious problems for most conventional processes unless extensive sorting was done prior to the processing. The selection of this stream was based on its large volume and representative nature.

\subsection{Stream Compositions}

The percentages of the various components in each stream were based primarily on work pre znted in previous Engineering Design Files (EDFs). In addition, certain components were added to each stream to ensure that the remaining waste streams were enveloped. The molecular composition of each of the individual components was obtained from a variety of sources. ${ }^{8-13}$

\subsubsection{Series 743 Sludge}

Table 2 lists the composition of the 743 Series Sludge. The basic volume percentages were obtained from an internal EG\&G Idaho Engineering Design File. ${ }^{4}$ In addition, this volume was supplemented with small amounts of mercury, lithium, plutonium, and americium.

\subsubsection{Estimate of Remaining Waste}

Stream 2 is based loosely on the description given in Table 1 and the descriptions listed in Content Code Assessment for INEL Contact-H.:ndled Stored Transuranic Wastes. ${ }^{8}$ In addition, soil, concrete, high-efficiency particulate air (HEPA) filters, plastics, lithium, and mercury have been added to represent the waste more completely. The volume percentages for the components were based on a report by James O. Low. ${ }^{5}$ Table 3 presents the composition of Stream 2. Fractions for waste types were determined based on 1971-1973 waste content code inventories developed from RFP were representative of the TRU waste buried at the Subsurface Disposal Area (SDA). 


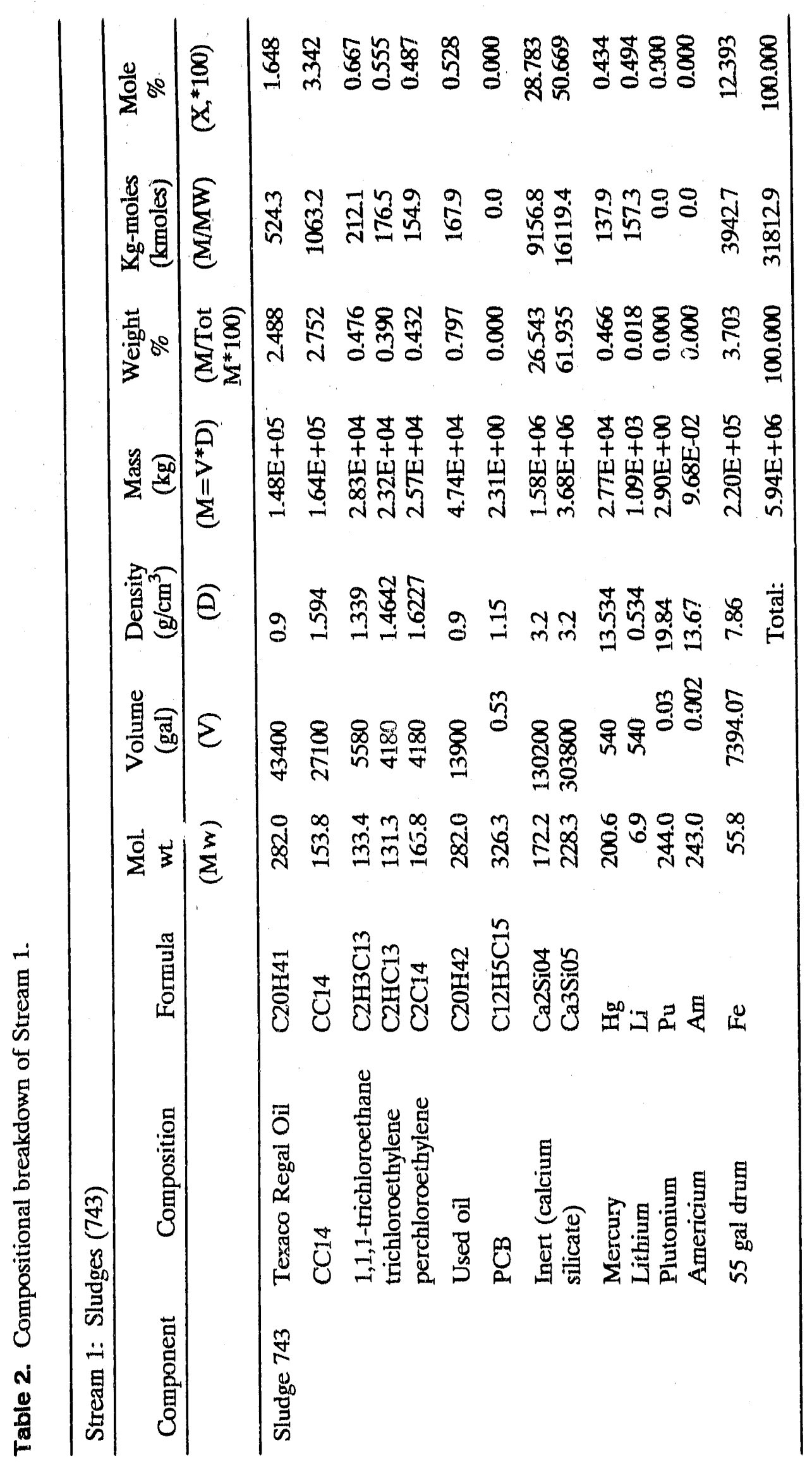




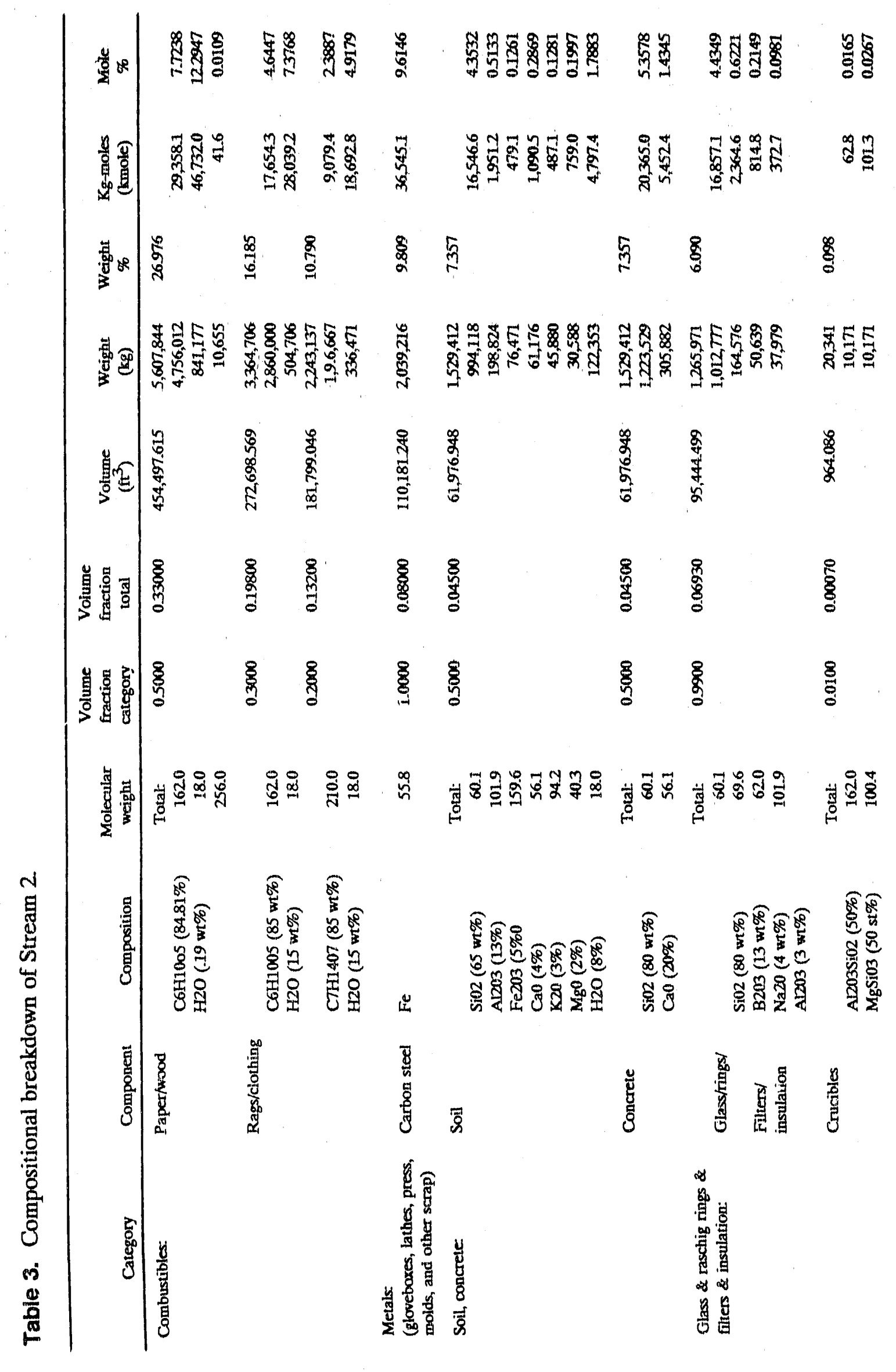




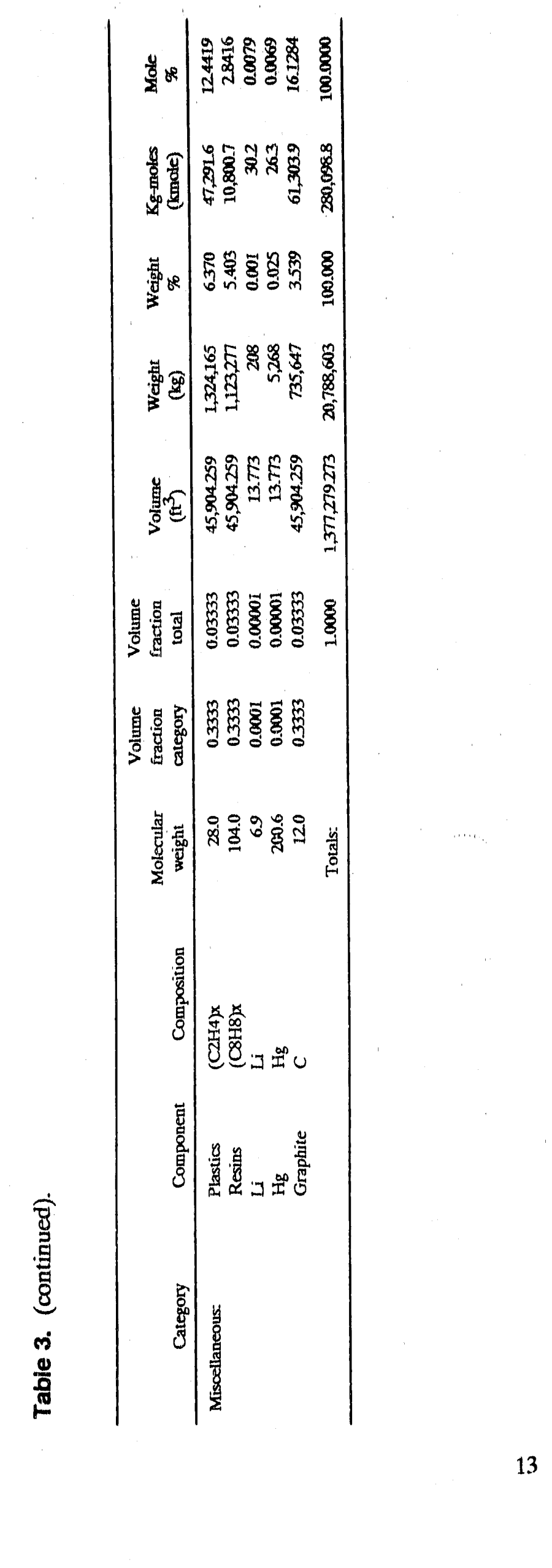




\section{PROCESS CONFIGURATION}

The basic configuration of the plasma pyrolysis system chosen consists of a main plasma chamber and a plasma afterburner followed by an off-gas treatment system. This project did not include optimization or trade-off studies for the system configuration.

The Plasma Pyrolysis Process Flow Diagram is shown in Figure 1. Stream numbers shown on the Process Flow Diagram correspond with those given in the mass and energy balance table in Appendix A.

\subsection{Main Plasma Chamber}

The main plasma chamber was patterned after the 125 ton/day Plasma Refuse Converter (PRC) design by PEC. PEC has conducted plasma waste conversion tests at the rate of 1 ton/hour, converting municipal solid waste into a fuel-rich gas and a vitrified inert solid. The results of these tests were used to design a 250 ton/day module called the Plasma Refuse Converter (Figure 2). The PRC consists of two $5 \mathrm{MW}$ pyrolysis reactors each feeditig 125 tons/day. Pyrolysis is the thermal decomposition of carbonaceous material in the absence of oxygen. After pyrolysis and vitrification, the volume reduction of the waste will be significant. ${ }^{\text {a }}$

\subsubsection{Inputs to the Reactor}

Hazardous waste can be accepted in drum form to the main plasma reactor by a common walking floor mechanism. The walking floor permits the controlled handling of mixed waste. The feed is assumed to be comprised of the compositions given in Tables 4 and 5.

Air is used as the plasma gas for the PRC reactor and was assumed to be the plasma gas for this study. The plasma torch will require $150 \mathrm{scfm}$ of air at $60-100 \mathrm{psig}$. It is important to note that the type of plasma gas used will have an impact on the amounts and types of products generated. Any gaseous medium is acceptable for use i.e., argon, helium, hydrogen, nitrogen, or, if appropriate, oxygen, carbon dioxide, water, etc. ${ }^{6}$ Trade-off and experimental studies would be beneficial in determining the best plasma gas for a particular system.

The plasma torch system will be equipped with a closed-loop cooling water system. Cooling water demand will be about 100 gallons/minute at a pressure of approximately $200 \mathrm{psig.}$

a. Personal correspondence (letter), Dr. Bud Camacho, Plasma Energy Corporation, Raleigh, North Carolina, November 1990. 


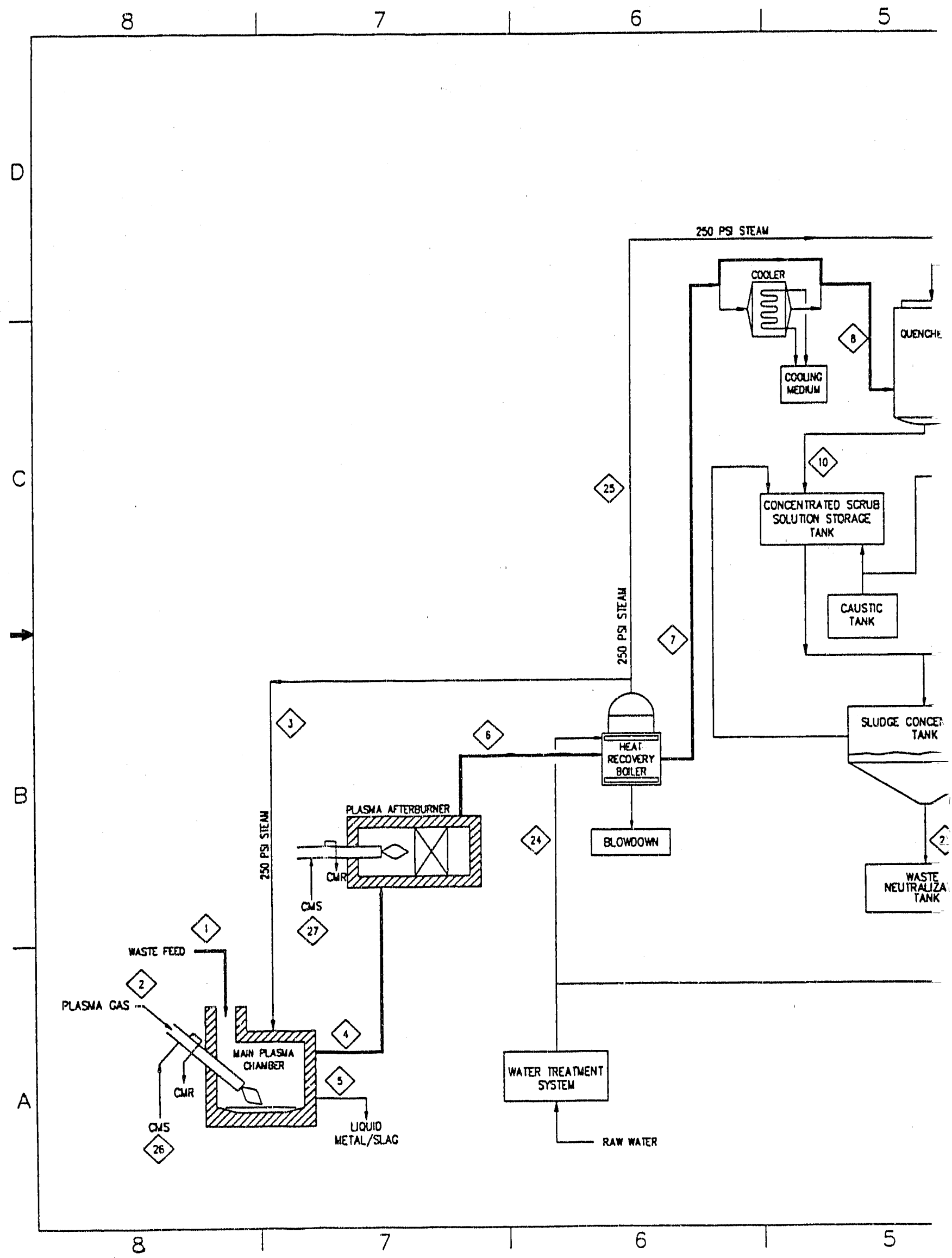

Figure 1. Process Flow Diagram. 


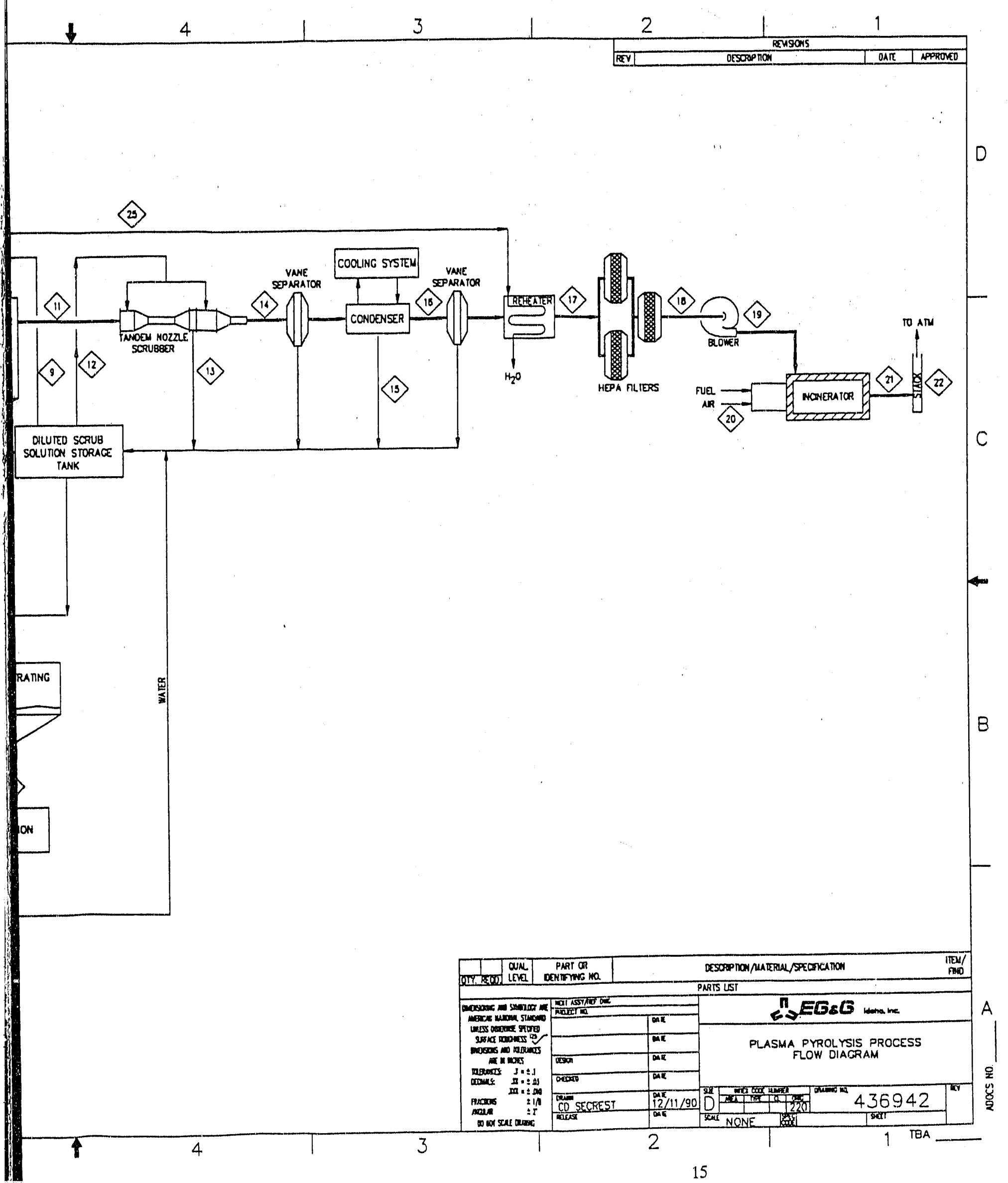




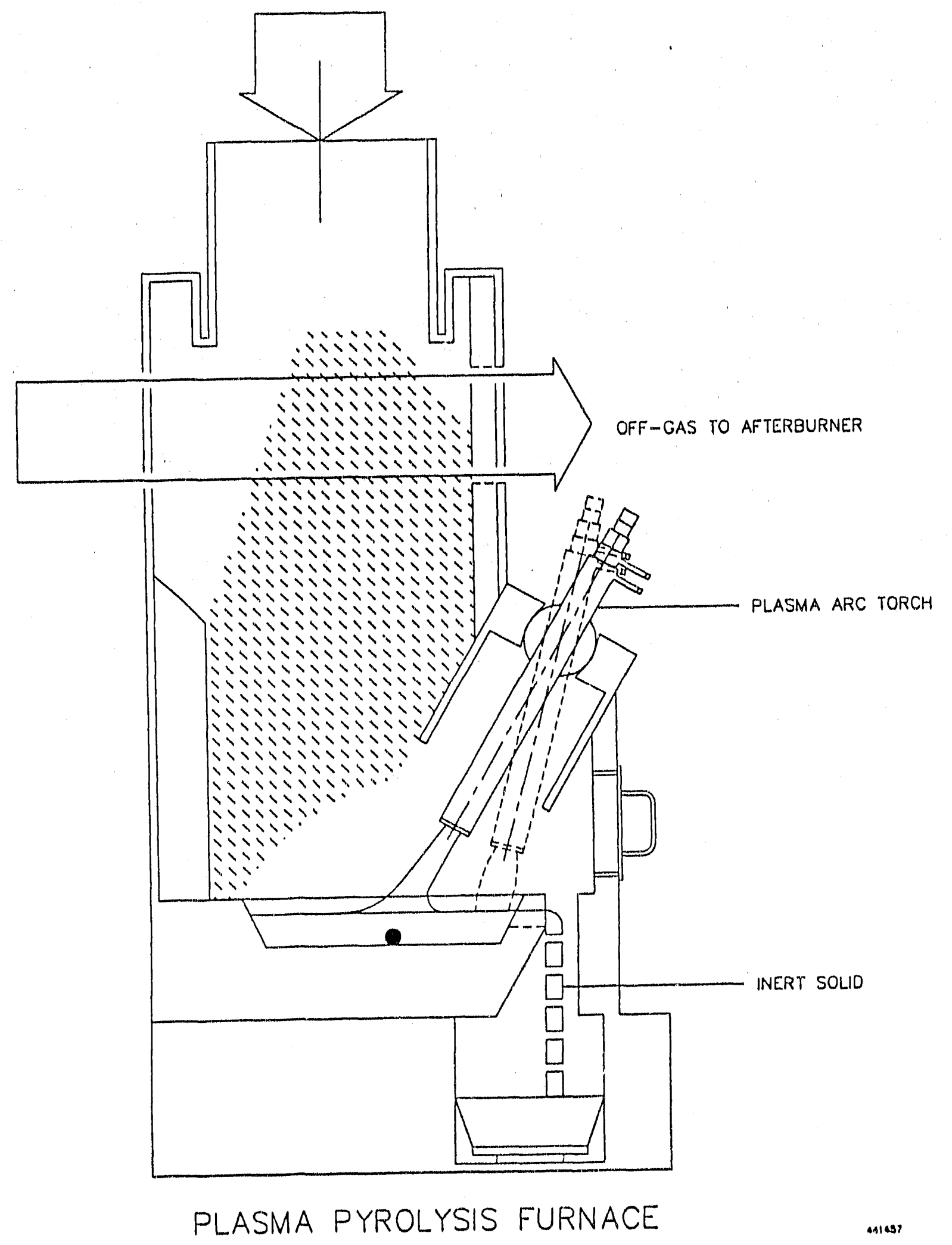

Figure 2. Plasma Refuse Converter from Plasma Energy Corporation. 


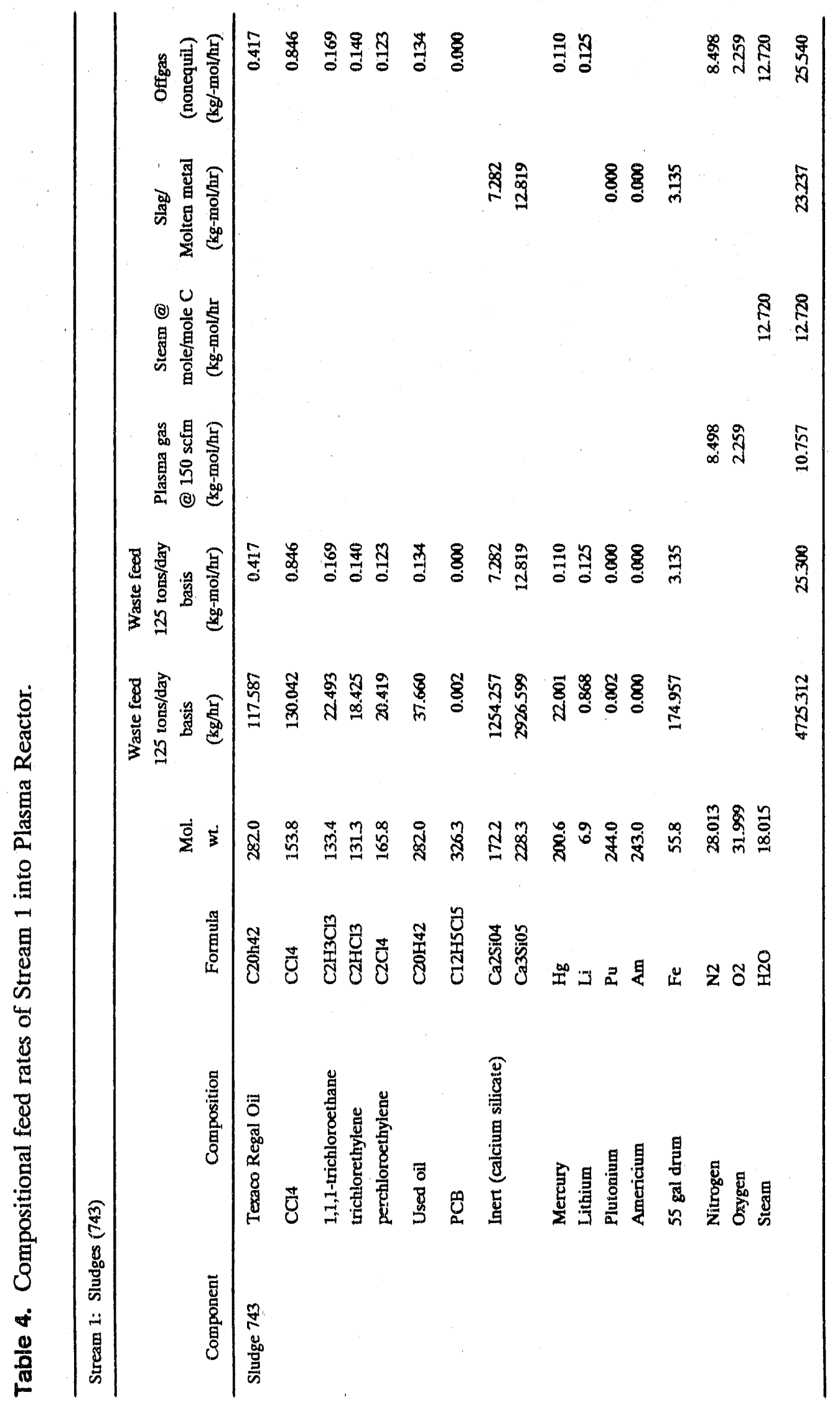




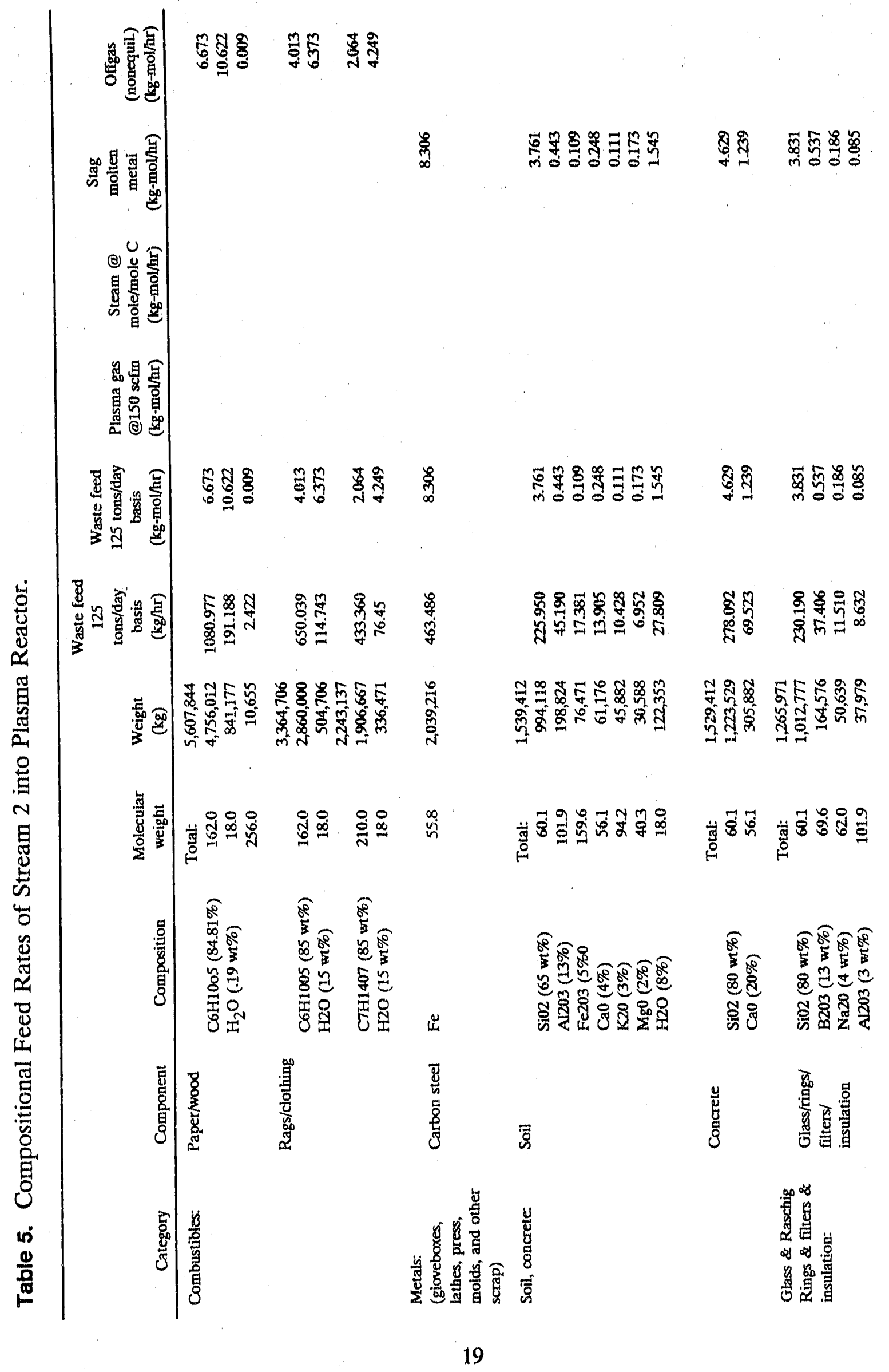




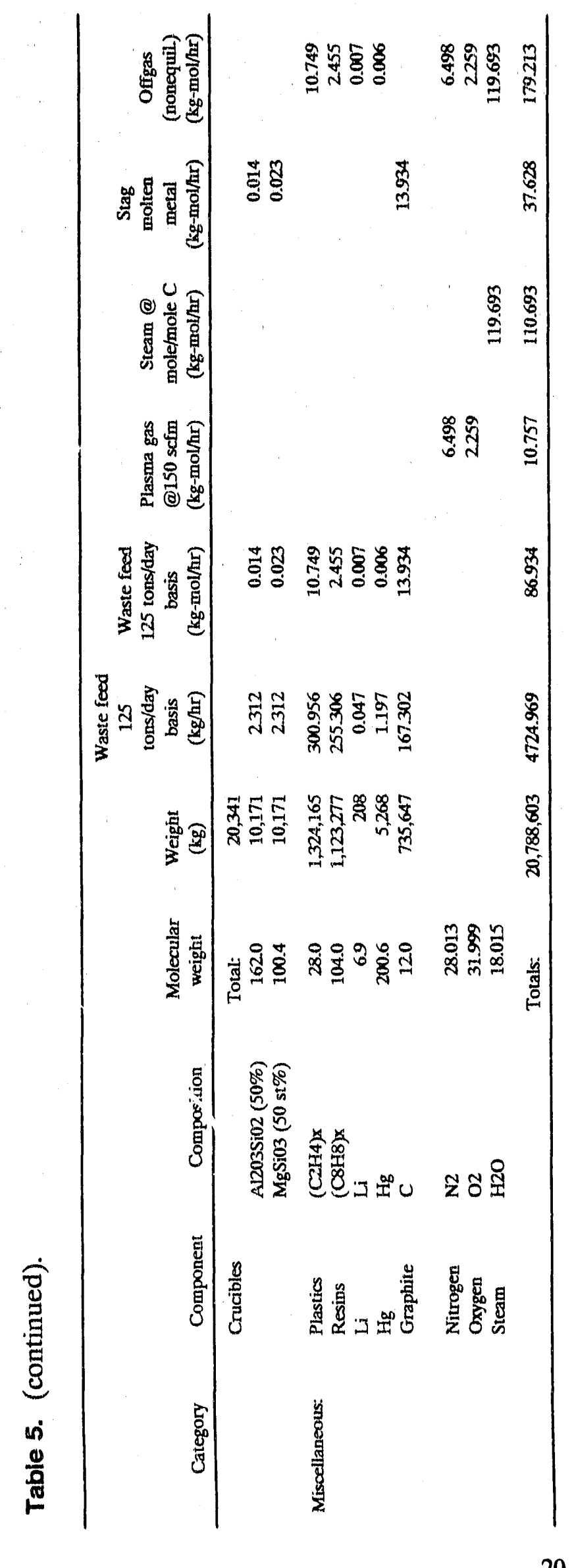


To minimize soot formation, one mole of $250 \mathrm{psi}$ steam/mole of carbon is injected into the reactor. Under pyrolyzing conditions, steam will react with soot (carbon) to form carbon monoxide and hydrogen.

The component weight percents, presented in Tables 2 and 3 , were used to define the composition of the feed stream entering the plasma reactor at a rate of 125 tons/day. This rate was chosen based on the capacity of the Plasma Energy Corporation PRC design. Tables 4 and 5 give the compositional breakdown in kgmoles/hr for streams 1 and 2, respectively.

\subsubsection{Outputs}

The temperature of pyrolysis, the heating rate, and the composition of the carbonaceous feed material taken together determine the make-up of the byproducts of the pyrolysis process. ${ }^{6}$ The relative amounts of byproducts from the process are highly dependent upon the feed composition. The organic material in the feed will be volatilized and broken down into atomic constituents and reformed into simple byproducts such as carbon monoxide, hydrogen, hydrochloric acid, nitrogen, etc. The temperature of the off-gas leaving the plasma reactor is assumed to be $1000^{\circ} \mathrm{C}$. The inorganic material will form a molten material (slag). The temperature of the molten bath is assumed to be $2000^{\circ} \mathrm{C}$. It is further assumed that sufficient residence time is provided to ensure essentially complete thermal destruction of the organics. After exiting the furnace, the moiten material is allowed to cool forming a crystalline, nonleachable slag.

In past studies exploring thermal melting operations for decontamination of TRU contaminated bulk metals, it was observed that the molten steel and slag form two distinct layers. The TRU contaminants are expected to be in an oxide form that will be dissolved into the slag. Any low melting temperature metals will melt and collect above or below the slag (depending upon density) and possibly allow for the bulk metal to be drawn off, separated, and reclassified as low level waste. The radioactive and hazardous heavy metals are also expected to remain dissolved within the slag. The resulting vitrified or ceramic product will retain these compounds following cooling such that the Environmental Protection Agency (EPA) Toxicity Characteristic tests for heavy metal leachability will consistently be met. ${ }^{7}$ Material process applications testing is needed to verify this expectation.

\subsection{Plasma Afterburner}

The main purpose of the afterburner is to ensure essentially complete decomposition of any hazardous organics that (not all organics escape) may have escaped from the main plasma pyrolysis reactor to achieve the required destruction and removal efficiencies. A plasma-type afterburner was chosen to be consistent with the goal of this study to evaluate plasma systems. A conventional combustion afterburner could also be used. The plasma torch in this scheme would use the influent 
gas to strike an arc and therefore no additional plasma gas is needed. The opinion of PEC is that an afterburner is not needed. Further studies are required to verify this and to determine the optimum process scheme.

\subsection{Off-gas System}

The main purpose of the off-gas system is to cool, scrub, and filter the effluent gas from the plasma systems. The off-gas system configuration is similar to an off-gas system design by PNL. The PNL off-gas system is an established system which can handle radionuclides, particulates, and acid gases. The major components of the off-gas system include: a boiler, a gas cooler, a quench tower and tandem nozzle scrubber, two scrubber solution tanks, a condenser, a reheater, mist eliminators (vane separators), HEPA filter assemblies, and a blower. The off-gas system contains a sophisticated control system with critical and informational sensors located throughout the process to ensure safe operation. These include thermocouples, flowmeters, pressure elements, gas monitors, back up equipment, etc.

\subsubsection{Heat Recovery Boiler}

The gas exiting the afterburner will be cooled to approximately $750^{\circ} \mathrm{F}$ in the heat recovery boiler by generating $250 \mathrm{psi}$ steam. The main purpose of the boiler is to cool the gas stream and to recover waste heat by producing steam to be used in the process. Steam is injected into the main plasma chamber and used in the reheater downstream in the off-gas system. Because more steam is produced than is needed, the excess steam could potentially be used to evaporate water from the sludge generated in the off-gas system (reducing volume), or used in other energy recovery applications such as power generation.

\subsubsection{Cooler}

The gas cooler is a finned air-to-glycol heat exchanger and used to further cool the off-gases before they enter the quench tower.

\subsubsection{Wet Scrubber System}

The wet scrubber system consists of a quench tower, a tandem nozzle scrubber, and a vane separator. In the quench tower, the gas is contacted with the circulating scrubbing solution to reduce the temperature to approximately $150^{\circ} \mathrm{F}$ by evaporation of water from the solution and to remove approximately $90 \%$ of any particulates and semivolatile radionuclides from the gas. The tandem nozzle scrubber is designed to remove an additional $90 \%$ of any remaining particulates that are greater than $0.5 \mu$ in diameter. In addition, it provides further cooling of the gas and condenses the 
remaining semivolatile components. Vane separator-type mist eliminators are used to romove all droplets greater than about $12 \mu$ in diameter.

Scrubber solution is circulated to the quench tower and tandem nozzle scrubber. The solution from the quench tower and scrubber is cooled through two single-stage heat exchangers before being returned to the process. Fresh caustic solution is made-up to the circulating solution to neutralize any acids in the off-gas. Sludge is collected and concentrated by gravity settling in the sludge concentration tank and sent to the waste neutralization tank. Excess steam generated from the plasma pyrolysis process could be used to reduce the sludge volume by cvaporation.

\subsubsection{Condenser}

Following the wet scrubber system, the gas flows through a condenser. The condenser provides additional decontamination of the off-gas by condensing and removing water. The second vane separator removes droplets $\geq 12$ microns.

\subsubsection{Reheater and HEPA Filter Assembly}

After exiting the condenser, the gas is reheated using steam generated by the heat recovery boiler. This slightly superheats the gas to ensure that there is no entrained mist to clog the HEPA filters. The first stage of filtration consists of two HEPA filters in parallel. During operation, one filter is used and the other remains as a back-up in case the operating filter becomes clogged. The primary filter can then be changed out during operation. Final decontamination of the off-gas particulates is achieved in the two-stage HEPA filter assembly.

\subsubsection{Blower}

The off-gas is drawn through the system components by an induced-draft, single-stage centrifugal blower. A back-up blower rated at one-fourth the capacity of the primary blower is provided to maintain a negative pressure in the event of primary blower failure.

\subsection{Incinerator}

The effluent gas from the off-gas system contains carbon monoxide, carbon dioxide, water vapor, hydrogen, and nitrogen. For the process scheme selected for this study, the effluent gas is incinerated to oxidize the $\mathrm{CO}$ producing an effluent which primarily consists of carbon dioxide, water vapor, oxygen and nitrogen. The oxidized efluent gas is then vented to the atmosphere.

The combustion takes place downstream of the off-gas treatment system for two reasons. Because a large amount of air is needed to completely oxidize the gas, combustion upstream of the 
off-gas system would significantly increase the gas volume through the system, and thus require larger, more expensive equipment. By incinerating the gas downstream, the size and costs of the equipment processing contaminated gases are reduced and a clean gas stream is oxidized in the incinerator producing simple nonhazardous products.

Secondly, the exit-gas from the plasma pyrolysis chamber contains a significant amount of unreacted carbon monoxide and hydrogen and at relatively high temperatures $\left(2500^{\circ} \mathrm{F}\right)$. Completing combustion of this gas immediately following the pyrolysis step increases the gas temperature further due to the exothermic nature of the combustion reactions. Combusting the hot off-gas from the main plasma chamber would produce unattractive byproducts, increase the amount of cooling required upstream of the quench tower, and require more exotic combustion chamber construction materials because of high temperatures. Since the production of oxides of nitrogen is a function of temperature, this type of operation would be expecied to result in higher effluent oxides of nitrogen concentrations.

The effluent gas from the off-gas system is combusted in a conventional gas incinerator. An assumption of $100 \%$ excess air was used to determine the gaseous effluent. The large amount of air reduces the combustion temperature and thus, will produce less oxides of nitrogen according to chemical equilibrium calculations. Because of the high heating value of incoming gas, minimal fuel is needed for the incinerator. To further reduce the oxides of nitrogen production, water could be injected into the incinerator. The off-gases are then exhausted to the stack, which is monitored continuously for radionuclides, oxides of nitrogen, and sulfur dioxide.

Because the heating value of the fuel-rich gas is simply lost if incinerated as shown, the gas could be used for other purposes such as producing steam to make electricity which could support the energy requirements for the torch. Again, trade off studies should be completed to determine superior and efficient energy benefits for this process. 


\section{MASS AND ENERGY BALANCES}

Mass balances were generated for the two leed streams delined earlier in section three of this report and are identified as Stream 1 and Stream 2 throughout this section. A feed rate of 125 tons/waste/day was used to determine the mass balances around one reactor. This feed rate was based ot the PEC Plasma Refuse Converter module design which has a capacity of 250 tons/waste/day using two $5 \mathrm{MW}$ pyrolysis reactors. The process is assumed to run in a semicontinuous mode with the reactor being fed in batches of 20-30 tons/charge as recommended by PEC. A stream flow rate summary of the major process streams is presented in Tables 6 and 7 for Stream 1 and Stream 2, respectively. The lully detailed mass balance table for each stream can be found in Appendix $\mathrm{A}$. The stream numbers given in the summury and detalled mass and energy balances correspond to the stream numbers on the Process Flow Diagram.

The following assumptions were made in determining the mass balances:

- The temperature in the main plasma chamber was assumed to be $2000^{\circ} \mathrm{C}$ in the slag (liquid phase) and $1000^{\circ} \mathrm{C}$ in the vapor phase based on discussions with PEC.

- One mole of steam per mole of carbon was used to determine the amount of steam required in the main plasma chamber as per the water shift reaction:

$$
\mathrm{C}+\mathrm{H}_{2} \mathrm{O}+\mathrm{Heat} \cdots \mathrm{CO}+\mathrm{H}_{2}
$$

- Vapor phase chemical equilibrium is assumed to apply in the main plasma chamber, the afterburner, and the incinerator. Chemical equilibrium was determined using NASA's CEC computer program which considers dissociation and ionizing of constituents.

- Liquid and solid entrainment was neglected throughout the system.

- The ASPEN simulation program was used 10 model the off-gas system with the following assumptions:

- Solid particulates were not modeled

- Heat losses from the system were neglected

- Henry's Law was used to deterınine the solubility of $\mathrm{HCl}$ in water

- Vapor/liquid equilibrium was obtained at each equipment component.

The main plasma furnace will be the most significant energy consumer. A detailed energy balance around the main plasma chamber was calculated. The amount of energy required to melt 
Table 6. Mass and energy summary for treatment of Stream 1 (sludges).

\begin{tabular}{|c|c|c|c|c|c|c|c|c|}
\hline stream numbor & 1 & 2 & 3 & 5 & 6 & 20 & 21 & 22 \\
\hline Stream name & Feed & Plasma gas & $\begin{array}{l}\text { Injected } \\
\text { steain }\end{array}$ & Slug & $\begin{array}{l}\text { Afterburner } \\
\text { offgas }\end{array}$ & $\begin{array}{c}\text { Incinerator } \\
\text { air }\end{array}$ & $\begin{array}{c}\text { Incinerator } \\
\text { offgas } \\
\text { to stack }\end{array}$ & $\begin{array}{l}\text { To } \\
\text { atm }\end{array}$ \\
\hline $\begin{array}{l}\text { Tomperature } \\
\text { (K) }\end{array}$ & 298 & 298 & 478 & 2273 & 1644 & 298 & 1580 & 1580 \\
\hline $\begin{array}{l}\text { Tomperature } \\
\text { (II) }\end{array}$ & 77 & 77 & 401 & 3632 & 2500 & 77 & 2384 & 2384 \\
\hline Toial Kgmol/hr & 25,03 & $10.75^{\circ}$ & 12.72 & 23.236 & 48.41 & 145.056 & 176,801 & 176.614 \\
\hline Total $\mathrm{Kg} / \mathrm{hr}$ & 472.5 & 310 & 229 & 4355 & א)9 & 4183 & 4957 & 4952 \\
\hline lotal Lb/hr & 10417 & 684 & 505 & 9601 & 2005 & 9223 & 10929 & 10917 \\
\hline Phase & $s$ & G & $\mathrm{G}$ & $S$ & $\mathrm{a}$ & G & $\mathrm{G}$ & (3) \\
\hline
\end{tabular}

Table 7. Mass and energy summary for treatment of Stream 2.

\begin{tabular}{|c|c|c|c|c|c|c|c|c|}
\hline Stream number & 1 & 2 & 3 & 5 & 6 & 20 & 21 & 2.2 \\
\hline Stream name & Feed & Plasma gas & $\begin{array}{l}\text { In) } \begin{array}{l}\text { steded } \\
\text { steam }\end{array}\end{array}$ & Slag & $\begin{array}{l}\text { Afterburner } \\
\text { offgas }\end{array}$ & $\begin{array}{c}\text { Incinerator } \\
\text { alr }\end{array}$ & $\begin{array}{c}\text { Inuinerator } \\
\text { offgas } \\
\text { to stack }\end{array}$ & $\begin{array}{l}\text { T'o } \\
\text { alm }\end{array}$ \\
\hline $\begin{array}{l}\text { Temperature } \\
\text { (K) }\end{array}$ & 298 & 298 & 478 & 2273 & 1644 & 298 & 1580 & 1580 \\
\hline $\begin{array}{l}\text { Temperature } \\
\text { (F) }\end{array}$ & 77 & 77 & 401 & 3632 & 2500 & 77 & 2384 & 2384 \\
\hline Total Kgmol/hr & 86.394 & 10.757 & 119.693 & 37.689 & 369.853 & 1267.468 & 1484.226 & 1481.895 \\
\hline Total Kg/hr & 4725 & 310 & 2156 & 1596 & 5601 & 36554 & 42634 & 42567 \\
\hline Total Lb/hr & 10417 & 684 & 4754 & 3519 & 12349 & 80587 & 93993 & 889384.5 \\
\hline Phase & $S$ & $\mathrm{G}$ & G & $s$ & $G$ & $\mathrm{O}$ & $\mathrm{G}$ & $\mathrm{G}$ \\
\hline
\end{tabular}


and vaporize the feed was calculated using heats of formation and heat capacities for each component (Appendix B). ${ }^{9,10}$ Assumptions used for heat losses in this study were based upon PEC experience. According to PEC, the plasma arc torch will suffer approximately 10. 15\% water-cooling loss and the plasma reactor will suffer approximately a $100 \mathrm{~kW}$ to $150 \mathrm{~kW}$ loss through its refractory lining. Calculational results show that a $5 \mathrm{MW}$ torch will be required to treat Stream 1 and a $10 \mathrm{MW}$ torch (or the two $5 \mathrm{MW}$ reactor module) is required to treat Stream 2 under the assumed gas and slag temperature conditions. The difference is primarily due to the different organic content of cach stream. Based on a 125 tons/day feed rate and assuming operation of $24 \mathrm{hr} /$ day, the power requirement for the plasma pyrolysis process will be about $900 \mathrm{~kW} / \mathrm{hr} /$ ton of Stream 1 and $1800 \mathrm{~kW} / \mathrm{hr} /$ ton of Stream 2 (Appendix B). 


\section{COST ESTIMATE}

A cost estimate was prepared for the plasma pyrolysis process described in this study. The cost identified in the estimate is based on December 1990 dollars. An escalation sheet is included with the detailed estimate in Appendix $\mathrm{C}$ for use if escalation is required. The ROM estimated total cost for the process is $\$ 21$ million. The total cost can be broken down as follows:

Summary of ROM Total Costs:

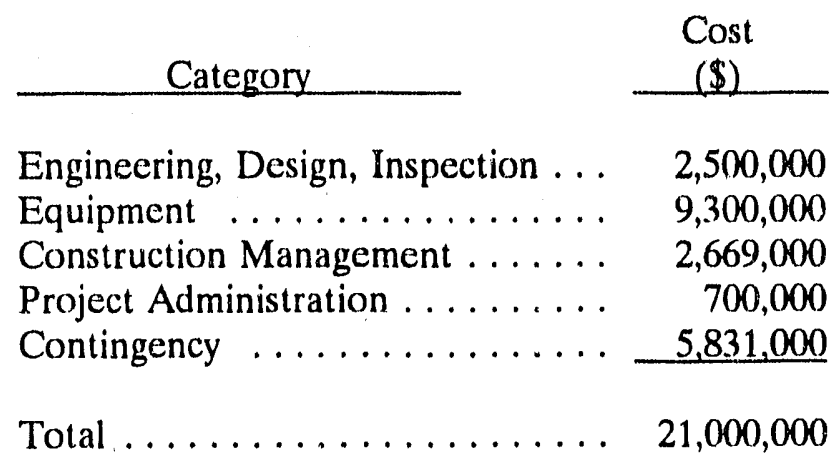

The ROM equipment costs can be broken down further as follows:

Summary of ROM Equipment Costs:

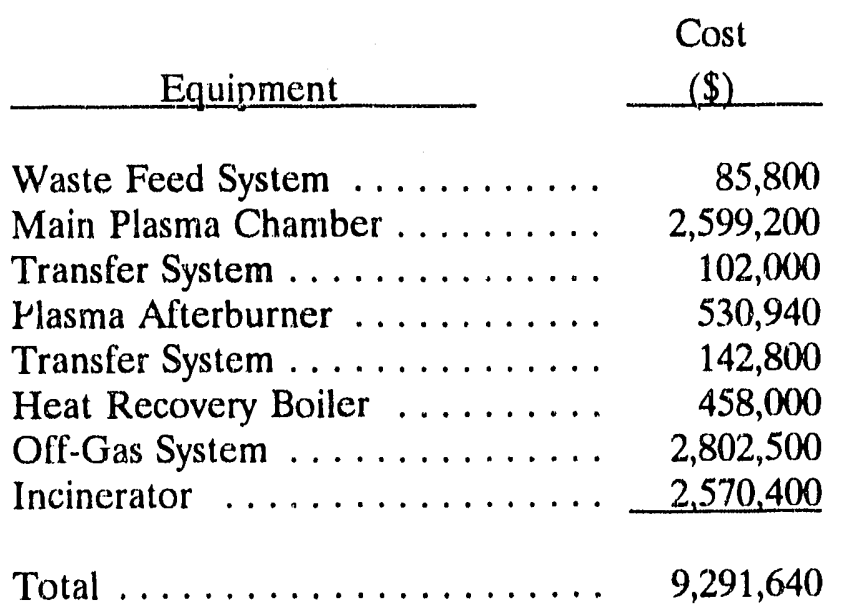

In this ROM cost estimate, the building to house the Plasma Pyrolysis Process is assumed to contain heating and ventilation equipment sized to handle the process. Other items assumed to already exist include a crane, office rooms, water and sewer, fire and alarm systems, radiation and contamination control, etc. It is assumed that the majority of the National Environmental Protection Act (NEPA)/Environmental documentation will be included in this building cost. 
The estimated total costs and equipment costs in December 1991 dollars are $\$ 21.8$ and $\$ 9.6$ million respectively. The assumptions used to prepare this estimate and additional details are given in Appendix $\mathrm{C}$.

The estimate discussed above does not include feed pretreatment. A cost estimate for an auger/shredder feed pretreatment system is included as pages C-9 and C-10 in Appendix C. The estimated total costs and equipment costs for the pretreatment system in December 1991 dollars are $\$ 1.2$ and $\$ 0.53$ million dollars, respectively. 


\section{RESULTS SUMMARY}

A scoping study was performed to evaluate the ROM energy requirement and equipment costs for a plasma pyrolysis thermal processing system as a possible waste treatment process for the INEL buried waste. Two representative INEL buried waste streams were identified for this study. Stream 1 is comprised of stabilized sludges and Stream 2 contains a assortment of mixed waste and soil. A feed rate of 125 tons/waste/day was used to calculate material and energy balances for the plasma pyrolysis treatment system.

The thermal processing waste treatment system chosen for evaluation consisted of a plasma pyrolysis reactor, a plasma afterburner, an off-gas treatment system with waste heat recovery, a final gas incinerator, and a stack. A conceptual flow sheet and cost estimate for this system were generated.

The power input requirement for the plasma pyrolysis reactor was calculated to be approximately $900 \mathrm{~kW} / \mathrm{hr} /$ ton of Stream 1 waste input and $1800 \mathrm{~kW} / \mathrm{hr} /$ ton of Stream 2 waste input. The ROM cost estimate for this total process system is $\$ 21.8$ million in December 1991 dollars. 


\section{RECOMMENDATIONS}

The calculations performed in this study were intentionally very limited in scope. The purpose was to obtain a first cut ROM estimate for input energy requirements and system costs expected to be required to process the INEL buried wastes in a plasma torch-based pyrolysis system. A single process configuration was evaluated. Other thermal processing systems and component systems are possible and need to be evaluated in the same manner. Other waste streams and variations require consideration. Variations on key assumptions utilized in the study (e.g., gas and slag temperatures, heat losses, pyrolysis vs. combustion/oxidation, oxygen enrichment vs. air, plasma gas composition, extent of waste heat recovery, incineration of waste prior to plasma melting of noncombustibles, etc.) and other process variations need to be examined in similar analytical studies.

Optimization and trade-off studies are recommended to evaluate need for and type of afterburner; off-gas incineration versus utilization of off-gas containing $\mathrm{CO}$ and $\mathrm{H}_{2}$; and cost effectiveness of energy recovery and utilization. 


\section{REFERENCES}

1. S. Hailey, Plasma Candidate Waste Stream Survey, SMH-01-90, October 1, 1990.

2. L. J. Stalely, "Hazardous Waste Decontamination with Plasma Reactors," Hazardous Materials Control, March/April 1990, pp. 67-71.

3. H. M. Freeman, Standard Handbook of Hazardous Waste Treatment and Disposal, New York: McGraw-Hill Book Company, Inc., 1989, pp. 8.169-8.177.

4. E. C. Garcia and J. L. Knight, Hazardous Organic Content of Pit 9, EG\&G Idaho, Inc., EDF BWP-ISV-002 Rev. 0, January 1989.

5. J. O. Low, Annual Technology Assessment and Progress Report for the Buried Transuranic Waste Program at the Idaho National Engineering Laboratory, EGG-2429, December 1985.

6. S. L. Camacho, "Plasma Pyrolysis of Medical Waste," Plasma Symposium, Hyatt Rickeys, Palo Alto, CA, March 7-9, 1990.

7. R. Geimer, Science Applications International Corporation, "Plasma Arc Incineration of a Supercompacted Waste Form," Plasma Applications to Waste Treatment Conference, Idaho National Engineering Laboratory, Idaho Falls, Idaho, January 16-17, 1991.

8. T. L. Clements, Jr., Content Code Assessments for INEL Contact-Handled Stored Transuranic Wastes, WM-F1-82-021, EG\&G Idaho, Inc., October 1982.

9. R. H. Perry and D. W. Green, Perry's Chemical Engineers' Handbook, 6th Edition, McGraw-Hill Book Company, Inc., New York, 1984.

10. R. C. Weast, CRC Handbook of Chemistry and Physics, 59th Edition, CRC Press, Boca Raton, Florida, 1974.

11. C. A. Wentz, Hazardous Waste Management, New York: McGraw-Hill Book Company, Inc., 1989.

12. L. Theodore and J. Reynolds, Introduction to Hazardous Waste Incineration, New York: John Wiley \& Sons Publishing Co., 1987.

13. T. L. Clements, Jr. and D. E. Kudera, TRU Waste Sampling Program: Vol. I-Waste Characterization, EGG-WM-6503, September 1985.

14. Gordon and McBride, Computer Program for Calculation of Complex Chemical Equilibrium Compositions, Rocket Performance, Incident and Reflected Shocks, and Chapman-Jouguet Detonations, NASA SP-273, March 1976. 
Appendix A

Mass Balance Tables

A-1 


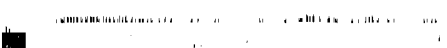

A-2 
STREAM ONE

COMPONENTS

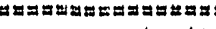
Texaco Regal Oll

Carbon Tetrachloride

1,1,1-trlohloroethane

inchlorethylene

perchloroethylane

Used of (C20.Hद2)

PCB's

Calctum Silcate (CaLsto4)

(Cass)05)

Mercury
Wthtum

pTutonlum

Americium

Carbon Steel

त.

$\mathrm{CO2}$

मर०

$\mathrm{HCl}$

Hic

CHद

oxygen

Nitrogen

ITCT

प. 2012

$\mathrm{NHI3}$

CI

NO

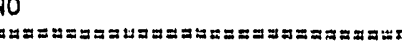
Total, ( kgmoles/hour)

Total, ( $\mathrm{kg} / \mathrm{hour}$ )

phase

Temperature (K)

pressure (Atm)

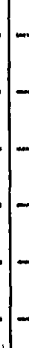

1

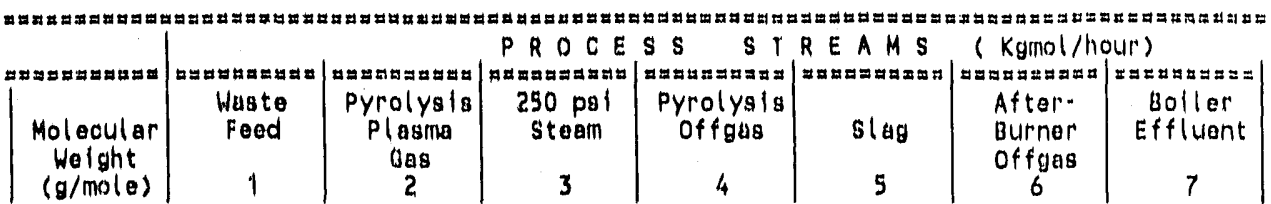

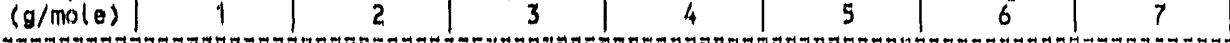

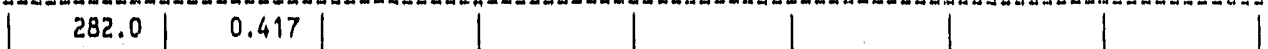

$\frac{153.8}{135.4}-0.846$

$131.3-0.140$

165.8

282.0

0.123

उ26. 3

$172 . ?$

$228 . \overline{3}$

0.134

200.6

6.9

trace

244.0

243.0

55.8

28.0

44.0

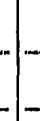

18.0

36.4

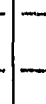

2.0

16.0

1.0

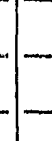

32.0

28.0

42.4

84.8

17.0

35.5

30.0

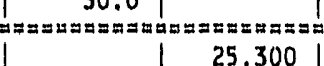

$=12 x=2 x=$

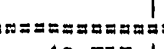

4725.368

H

208.15

10.757

$-310.232$
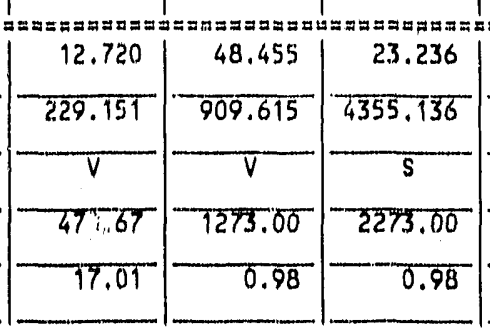

23.236

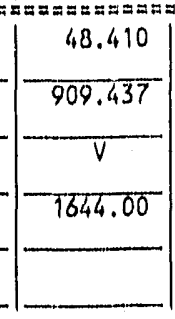

$==z= \pm=$

48.410

4355.136

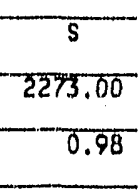

909.437

$\mathrm{V}$

672.04

0.97 
Mass Balanoe Table for stroam 1

STREAM ONE

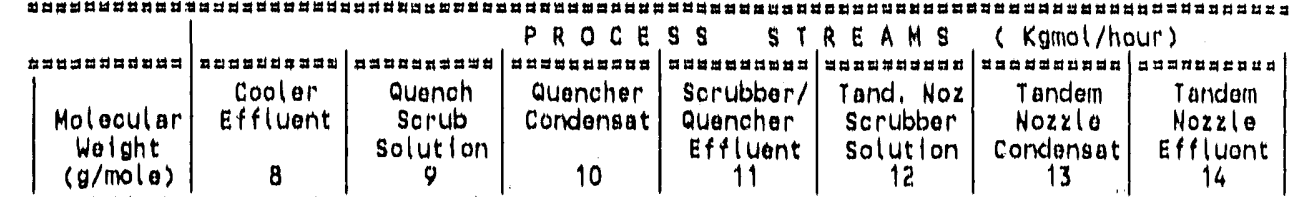

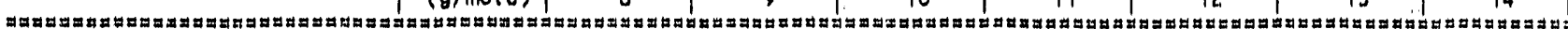

\begin{tabular}{|c|c|c|c|c|c|c|c|c|}
\hline Taxaco Regal oil & 282.0 & & & & & & & \\
\hline Carbon Tetrachlor de & 153.8 & & & & & & & \\
\hline 1.1.1-trichloroethane & 735.4 & & & & & & & \\
\hline तrtohlorethytene & 131.5 & & & & & & & \\
\hline perchloroethylene & 765.8 & & & & & & & \\
\hline U日ad oा (C20.1142) & 282.0 & & & & & & & \\
\hline PCE's & 326.3 & & & & & & & \\
\hline Calolum stlicate (CarsioG) & 172.2 & & & & & & & \\
\hline (Ca3sTo5) & -228.3 & & & & & & & \\
\hline Marcury & 200.6 & 0.110 & & 0.110 & & & & \\
\hline Lithtum & 6.9 & & & & & & & \\
\hline plutonium & $244.0^{\circ}$ & & & & & & & \\
\hline Amtriclum & 243.0 & & & & & & & \\
\hline Carbon stool & 55.8 & & & & - & & & \\
\hline$\overline{C O}$ & 28.0 & -11.9657 & & 0.006 & 17.9588 & & 0.0259 & 11.934 \\
\hline$\overline{\mathrm{CO}}$ & 44.0 & 0.762 & & 0.0103 & 0.7576 & & 0.0332 & 0.7183 \\
\hline$\overline{\mathrm{H} 20}$ & 18.0 & 3.7448 & 65.3173 & 50.9827 & 18.079 & 122.4699 & 129.9082 & 10.6407 \\
\hline HCI & 36.4 & 4.6765 & & $4.6765^{\prime \prime}$ & & & & , \\
\hline $\bar{H}$ & 2.0 & 18.5292 & & & 18.52 .93 & & & 18.5293 \\
\hline$\overline{\mathrm{CH}} 4$ & 16.0 & & & & & & & \\
\hline $\bar{H}$ & $-\sqrt{.0}$ & 0.002 & & 0.002 & & & & \\
\hline Oxygen & 32.0 & & & & & & & \\
\hline Witrogen & $28.0^{\circ}$ & 8.4957 & & 0.0038 & 8.4919 & & 0.016 & 8.4756 \\
\hline Tता & 42.4 & 0.124 & & 0.124 & & & & \\
\hline II2Cा2 & 84.8 & & & & & & & \\
\hline$\overline{\mathrm{NH3}}$ & 17.0 & & & & & & & \\
\hline$\overline{c T}$ & 35.5 & & & & & & & \\
\hline 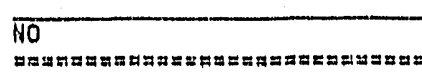 & $|-30.0|$ & 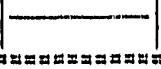 & 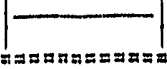 & 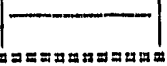 & 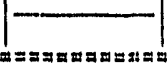 & 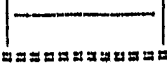 & ดมะ & \\
\hline Total, ( kgmoles/hour ) & & 48.410 & 65.317 & 5.9 .915 & 57.812 & 122.470 & 129.983 & 50.298 \\
\hline Total, ( $\mathrm{kg} /$ hour $)$ & & 909.428 & $\pi 176.691$ & 1115.972 & 969.003 & 2206.295 & 2342.919 & 832.360 \\
\hline Phase & & $\bar{v}$ & $T$ & $\bar{L}$ & V & $T$ & $T$ & V \\
\hline Temperature $(K)$ & & 672.04 & 204.26 & 352.22 & 339.22 & 294.26 & -331.18 & 337.18 \\
\hline Pressure (Atm) & & 0.96 & 9.36 & & 0.95 & 7.36 & & $\overline{0.81}$ \\
\hline
\end{tabular}


STREAM ONE

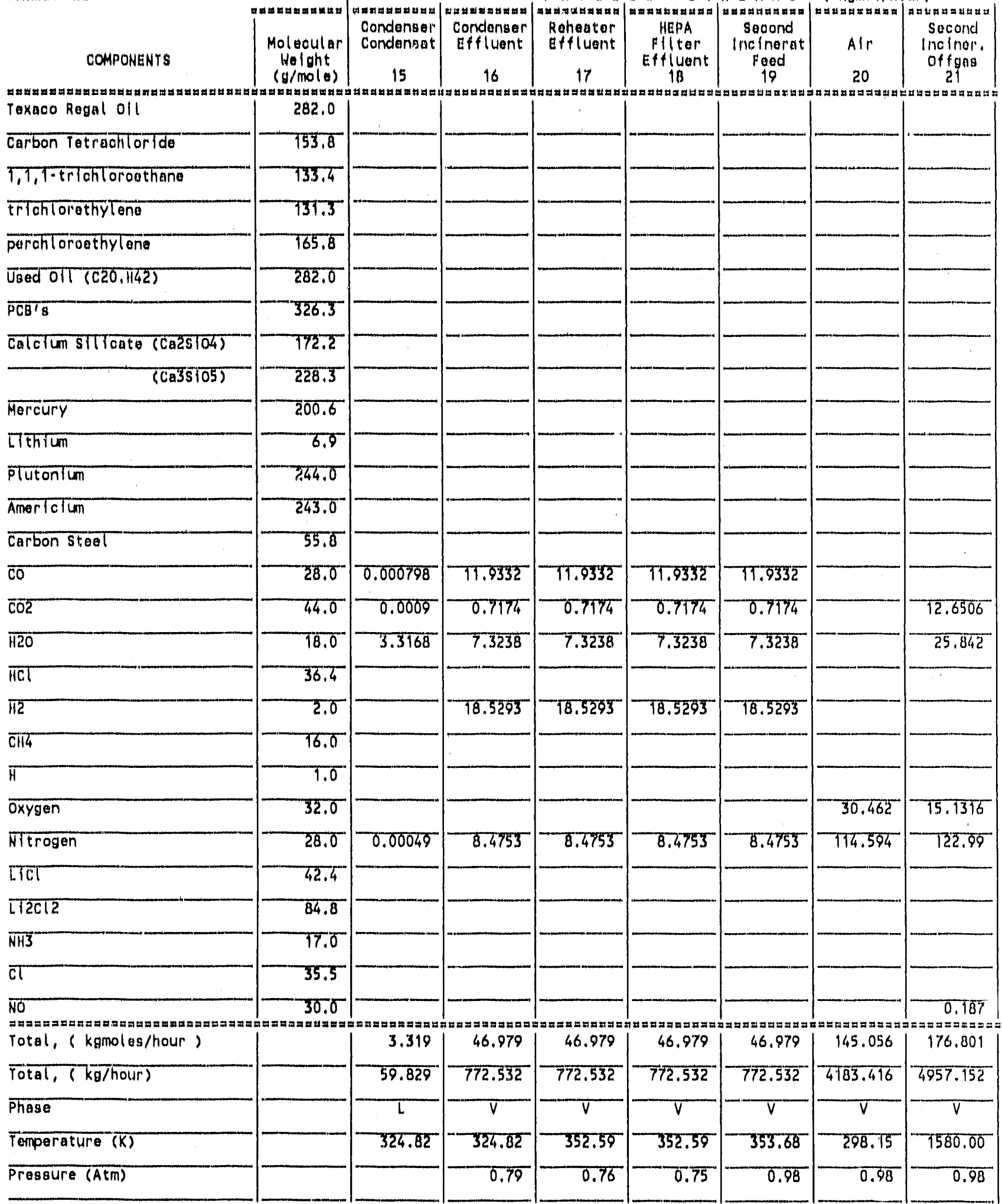


STREAM ONE

\section{COMPONENTS}

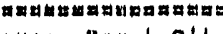
Texaco Regal Oll

Carbon TetrachToride

T,T,T-triohloroethane

tromorethytorie

perchtoroethylene

Used ort (C20.Hद2)

PCब's

Calctum STITCato (Cacsto4)

(Ca3sto5)

\begin{tabular}{|c|}
\hline Mercury \\
\hline TthTum \\
\hline plutonium \\
\hline Amartolum \\
\hline Carbon stoet \\
\hline$\overline{C O}$ \\
\hline$\overline{C O 2}$ \\
\hline $\bar{H} 20$ \\
\hline HCT \\
\hline स2 \\
\hline CH4 \\
\hline$\pi$ \\
\hline Oxygeri \\
\hline Nitrogen \\
\hline TाCT \\
\hline पा2वा2 \\
\hline$\overline{\mathrm{NH3}}$ \\
\hline $\bar{c} T^{-}$ \\
\hline
\end{tabular}

NO

NO Total, ( kgmoles/hour)

Total, ( $\mathrm{kg} /$ hour)

Phase

Temperature $(K)$

Pressure (Atm)

733.4

131.3

165.8

282.0

326.3

172.2

228.3

700.6

244.0

$-55.8$

28.0

44.0

36.4

2.0

$\begin{array}{r}16.0 \\ \hline 1.0\end{array}$

28.0

42.4

84.8

35.5

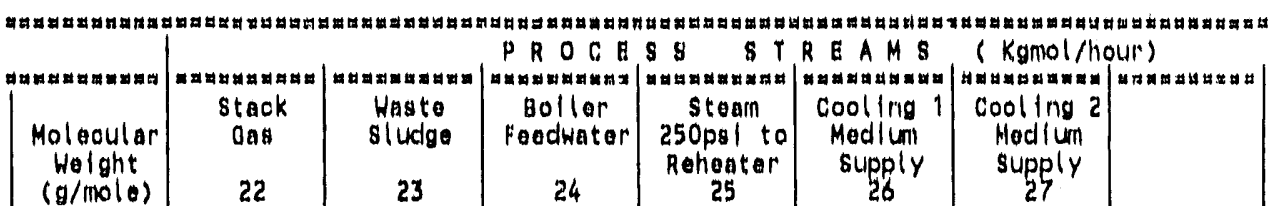

\begin{tabular}{ll|l|l|l|l}
22 & 23 & 24 & 25 & 26 & 27
\end{tabular}

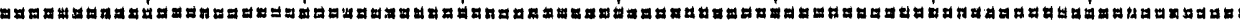

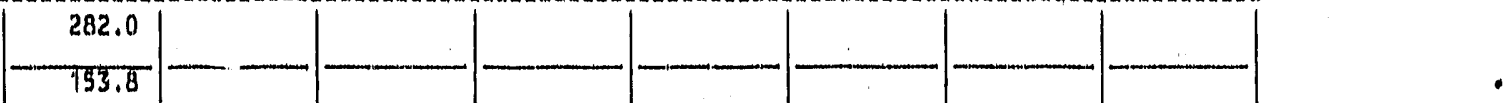

6.9

12.6506

- 25.842

32.0

15.1316

17.0

122.96

\begin{tabular}{|c|c|c|}
\hline & 176.614 & Did Not \\
\hline & 4951.900 & Tolculate \\
\hline & $y$ & s \\
\hline & $1580.00^{\circ}$ & \\
\hline & 0.98 & \\
\hline
\end{tabular}

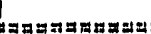

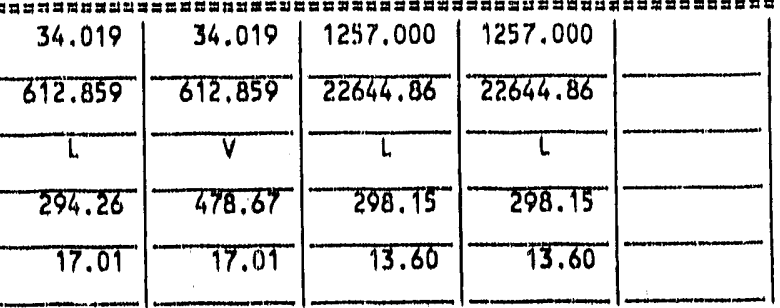




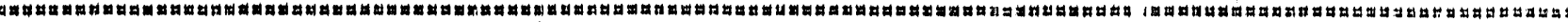
STREAM 2

PROCESS STREAMS (Komal/hour)

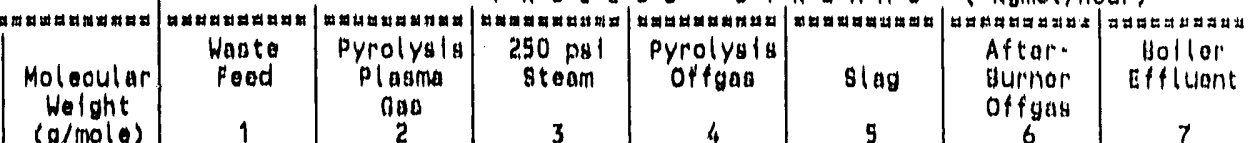

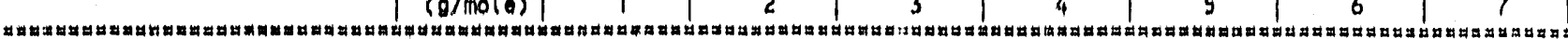
C6 110 OS

suttur

Cे

Fent

STó

AT2 03

Fo2 03

$\mathrm{CaO}$

$\mathrm{KCO}$

$\mathrm{MgO}$

NH3

हट 03

HaZ D

Aाद O3 ST Oद

मg 5 Tु

(त. 114$) x$

(C8 118$) x$

TthTum

Marcury

oraphtte
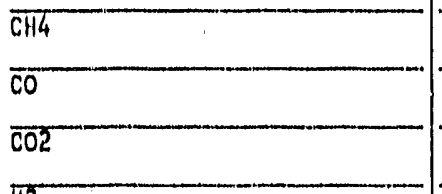

H2

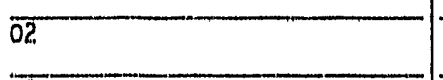

स2

$\pi$

TIOH

$162,0 \mid$
10,686

$-2$

256.0

0.009

210.0

55.8

60.1

$101.9^{\circ}$

159.6

36.1

94.2

40.3

17.0

69.6

62.0

162.0

100,4

दब.

104.0

6.9

2.00 .6

12.0

16.0

20.0

44.0

2.0

32.0

28.0

18.5

34.1

23.9

30.0

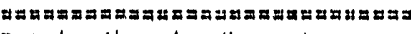

Total, (kymoles/hour J......

Total, ( $\mathrm{kg} /$ hour ) .............

Phase ...........n.

Temparature (K)

Pressure (atm)

(2..............
0.009
2.064

6.306

12.221

0.528

0.108

1.487

0.111

0.173

-

0.537

0.014

0.023

10.749

2.455

0.007

0.006

13.934

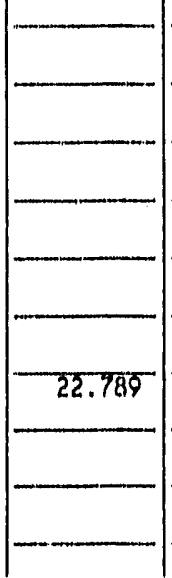

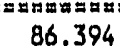

4725.32

$M$

208.15

0.98
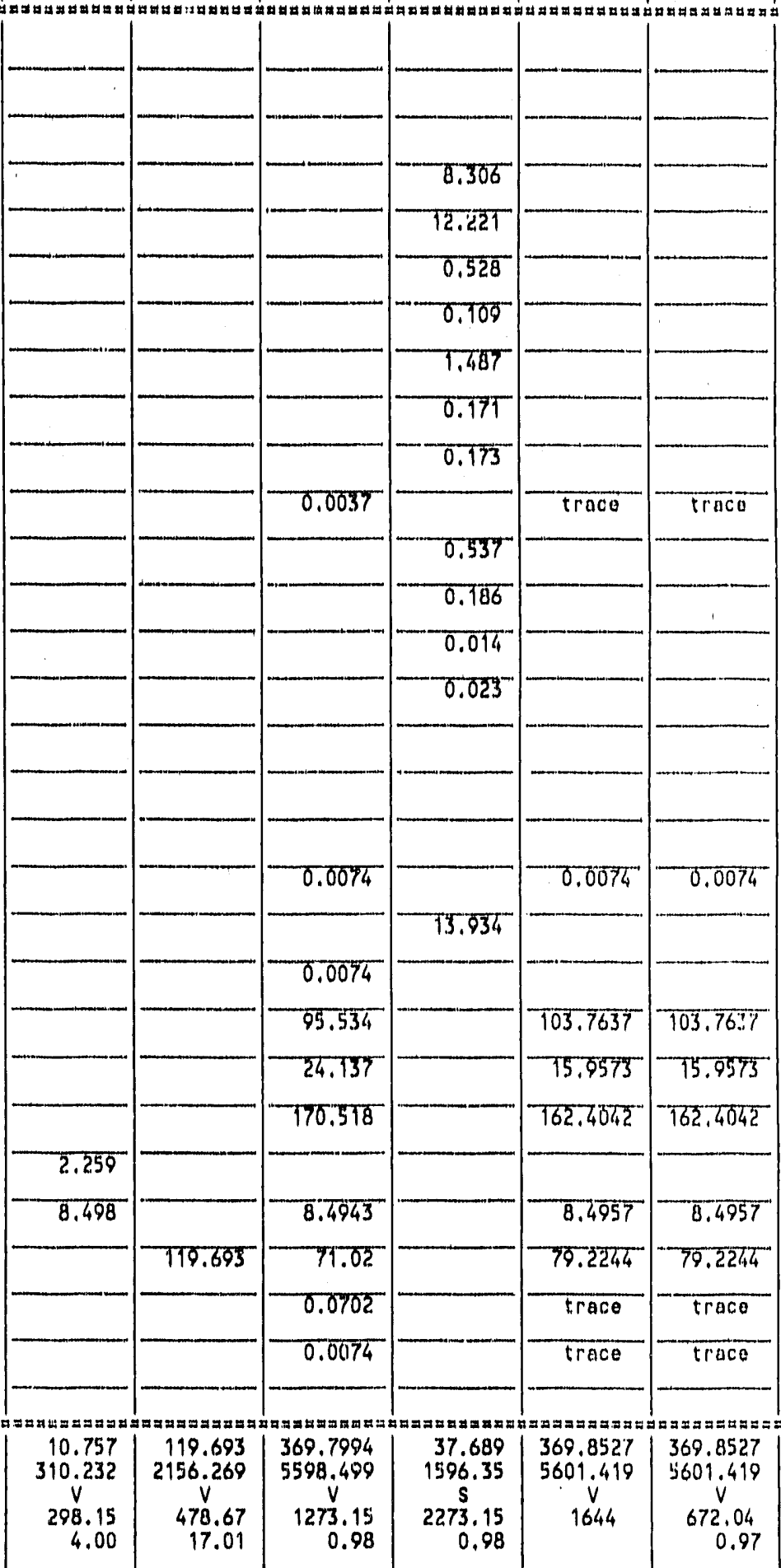


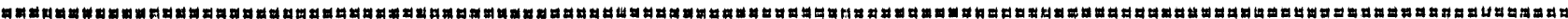
STREAM 2

PROCESS STREAMS (Kgmol/hour)

\begin{tabular}{|c|c|c|c|c|c|c|c|c|}
\hline COMPONENTS & $\mid \begin{array}{c}\text { Mol ooular } \\
\text { Welght } \\
(g / \text { mola })\end{array}$ & 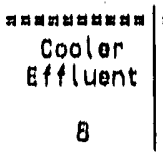 & 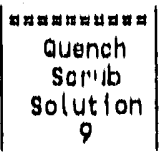 & $\left|\begin{array}{c}x=1 \text { and } \\
\text { Quencher } \\
\text { Condensat } \\
10\end{array}\right|$ & 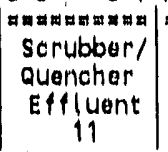 & $\begin{array}{c}\text { Tand. Noz } \\
\text { Tandantint } \\
\text { Sorubber } \\
\text { Solut lon } \\
12\end{array}$ & $\begin{array}{c}\text { Tanden } \\
\text { Tanden } \\
\text { Nozzlo } \\
\text { Condonsace } \\
13\end{array}$ & 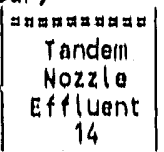 \\
\hline व & 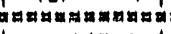 & 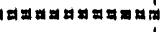 & ㅉำ & 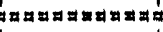 & 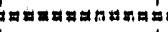 & वाघ & & \\
\hline C6 $\mathrm{H} 1005$ & 162.0 & & & & & & & \\
\hline sulfur & 256.0 & & & & & & & \\
\hline C7 114 or & 210.0 & & & & & & & \\
\hline$\overline{F e}$ & 55.8 & & & & & & & \\
\hline sTo2 & 60.1 & & & & & & & \\
\hline Aा203 & $101.9^{\circ}$ & & & & & & & \\
\hline Fec os & 159.6 & & & & & & & \\
\hline$\overline{\mathrm{CaO}}$ & 56.1 & & & & & . & & \\
\hline $\mathrm{K} 20$ & 94.2 & & & & & & & \\
\hline M90 & 40.3 & & & & & & & \\
\hline$\sqrt{H^{3}}$ & 17.0 & trace & & trace & & & & \\
\hline 82 03 & 69.6 & & & & & & & \\
\hline Na? 0 & 62.0 & & & & & & & \\
\hline Aा? 03 SI 02 & 162.0 & & & $\longrightarrow$ & & & & \\
\hline Mg SIOS & 100.4 & & & & & & & \\
\hline$\overline{(C 2}$ मद) $x$ & 28.0 & & & & & & & \\
\hline$(C B H 8) x$ & 104.0 & & & & & & & \\
\hline ithtum & 6.9 & & & & & & & \\
\hline Meroury & 200.6 & 0.0074 & & 0.0074 & & & & \\
\hline araphite & 12.0 & & & & & & & \\
\hline$\widehat{\mathrm{CH}} 4$ & 16.0 & & & & & & & \\
\hline$\overline{\mathrm{CO}}$ & 28.0 & 703.7637 & & & -103.7637 & & & 103.7637 \\
\hline$\overline{\mathrm{CO}}$ & 44.0 & -15.9573 & & & 15.9573 & & & 15.9573 \\
\hline Hב & 2.0 & 162.4042 & & & 162.4071 & & & 162.4041 \\
\hline$\overline{02}$ & 32.0 & & & & & & & \\
\hline $\overrightarrow{N 2}$ & 28.0 & 8.4957 & & & 8.4957 & & & $-\frac{8.4957}{10}$ \\
\hline HटO & 18.0 & 79.2244 & 501.6731 & 459.3479 & T21.5E18 & 940.7505 & 960.2602 & $64.0521^{\circ}$ \\
\hline म2S & 34.1 & trace & & trace & & & & \\
\hline LTOH & 23.9 & trace & & trace & & & & \\
\hline $\begin{array}{l}\text { NO } \\
\text { มฉ }\end{array}$ & 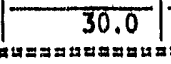 & 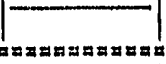 & 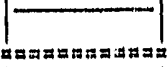 & 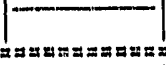 & 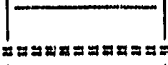 & 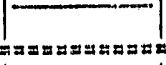 & 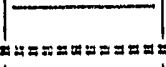 & 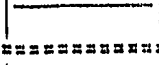 \\
\hline $\begin{array}{l}\text { Total, (kgmoles/hour ) } \ldots \ldots . . \\
\text { Total, ( } \mathrm{kg} / \mathrm{hour} \text { ) } \\
\text { Phase } \\
\text { lemporature (k) } \\
\text { Pressure (atm) }\end{array}$ & & $\left|\begin{array}{r}0 \\
v \\
672.04 \\
0.96\end{array}\right|$ & $\left|\begin{array}{c}501.6731 \\
9037.641 \\
i \\
294.26 \\
1.36\end{array}\right|$ & $\begin{array}{r}0 \\
0 \\
1.5 \\
342.66\end{array}$ & $\begin{array}{c}412.1826 \\
6364.017 \\
v \\
336.78 \\
0.95\end{array}$ & \begin{tabular}{|c}
940.7505 \\
16947.62 \\
$L$ \\
294.26 \\
1.36
\end{tabular} \mid & $\begin{array}{c}998.2602 \\
17983.66 \\
L \\
326.158\end{array}$ & $\begin{array}{c}354.6729 \\
5327.967 \\
v \\
326.158 \\
0.81\end{array}$ \\
\hline
\end{tabular}


Mass Balanco Table for stroam 2

व STREAM 2

PROCESS STREAMS (Kunol/hour)

\begin{tabular}{|c|c|c|c|c|c|c|c|c|}
\hline $\begin{array}{l}\text { COMPONENTS } \\
\text { Cथ }\end{array}$ & $\mid \begin{array}{c}\text { Molecular } \\
\text { Welght } \\
(g / n \text { ole }\end{array}$ & 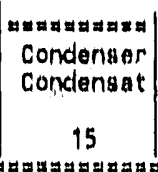 & 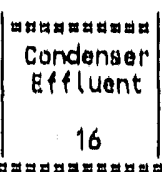 & $\begin{array}{c}\text { agmasamana } \\
\text { Reheater } \\
\text { Effluent } \\
17\end{array}$ & $\begin{array}{c}\text { HEPA } \\
\text { HIlter } \\
\text { Effluent } \\
18\end{array}$ & $\mid \begin{array}{c}\text { Second } \\
\text { Incinerat } \\
\text { feed } \\
19\end{array}$ & 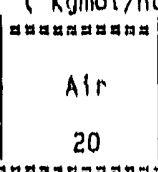 & $\mid \begin{array}{c}\text { a d a a a } \\
\text { gocond } \\
\text { Incinar. } \\
\text { of fgas } \\
21\end{array}$ \\
\hline C6 H1O OS & 162.0 & & & & & & & \\
\hline sutfur & $256.0^{-}$ & & & & & & & \\
\hline C7 $\mathrm{HT}_{4} \mathrm{O}^{-}$ & 210.0 & & & & & & & \\
\hline$\overline{F e}$ & 55.8 & & & & & & & \\
\hline STOZ & 60.1 & & & & & & & \\
\hline Aा2 0.3 & 101.9 & & & & & & & \\
\hline Fe2 03 & 158.6 & & & & & & & \\
\hline$\overline{\mathrm{CaO}}$ & 76.1 & & & & & & & \\
\hline$\overline{X 20}$ & $9 \% .2$ & & & & & & & \\
\hline$\overline{M g O}$ & -40.3 & & & & & & & \\
\hline Niा3 & 17.0 & & & & & & & \\
\hline Bट 03 & 69.6 & & & & & & & \\
\hline Naco & 62.0 & & & & & & & \\
\hline Alद 03 ST 02 & 162.0 & & & & & & & \\
\hline Mg SIO 03 & 100.4 & & & & & & & \\
\hline$(C 2 \pi / 4) x$ & 28.0 & & & & & & & \\
\hline$(C 8 H \theta) x$ & $104.0^{-1}$ & & & & & & & \\
\hline Tithium & 6.9 & & & & & & & \\
\hline Mercury & 200.6 & & & & & & & \\
\hline Graphite & -12.0 & & & & & & & \\
\hline$\overline{\mathrm{CH}}$ & $\sqrt{6.0}$ & & & & & & & \\
\hline$\overline{\mathrm{CO}}$ & 28.0 & & 103.7637 & 103.7637 & 103.7637 & $103.763 \%$ & & \\
\hline$\overline{C O 2}$ & 44.0 & & 15.9573 & 15.9573 & 15.9573 & -15.9573 & & 119.714 \\
\hline$\pi$ & $-m-2.0$ & & 162.4041 & 162.4041 & 162.4041 & 162.4041 & & \\
\hline$\overline{02}$ & 32.0 & & & & & & 266.168 & $901 . \overline{314}$ \\
\hline$\overline{\mathrm{N}}$ & 28.0 & & 8.4957 & 8.4957 & 8.4957 & 8.4957 & 1001.3 & -1008.62 \\
\hline$\overline{H 2 O}$ & 18.0 & 4.5747 & $59.677 \pi$ & 59.4774 & 59.7774 & 58.4774 & & 162.247 \\
\hline II2s & 34.1 & & & & & & & \\
\hline$L^{T}-11$ & 23.6 & & & & & & & \\
\hline 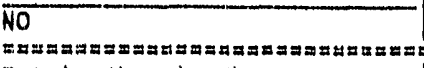 & 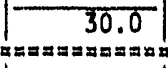 & & & & & & & 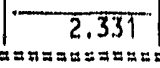 \\
\hline $\begin{array}{l}\text { Total, (kgmoles/hour ) } \ldots . . . \\
\text { Total, }(\mathrm{kg} / \mathrm{hour}) \\
\text { Phase } \\
\text { Temperature }(\mathrm{k}) \\
\text { Pressure (atth) }\end{array}$ & & $\begin{array}{r}4.5747 \\
82.41322 \\
4 \\
324.82\end{array}$ & $\begin{array}{r}350.0982 \\
5245.556 \\
v \\
324.82 \\
0.70\end{array}$ & $\begin{array}{r}350.0982 \\
5245.556 \\
v \\
352.59 \\
0.76\end{array}$ & $\begin{array}{r}350.0902 \\
52.45 .556 \\
y \\
352.59 \\
0.75\end{array}$ & $\begin{array}{c}350.0982 \\
5245,556 \\
V \\
353.67 \\
0.98\end{array}$ & $\begin{array}{r}1267.468 \\
36553.78 \\
V \\
298.15 \\
0.88\end{array}$ & $\begin{array}{c}1484.226 \\
42634.39 \\
V \\
1625.3 \\
0.98\end{array}$ \\
\hline
\end{tabular}




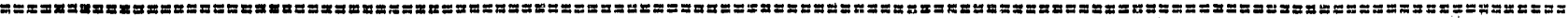
STREAM 2

PROCESS STREAMS ( Kgmol/hour)

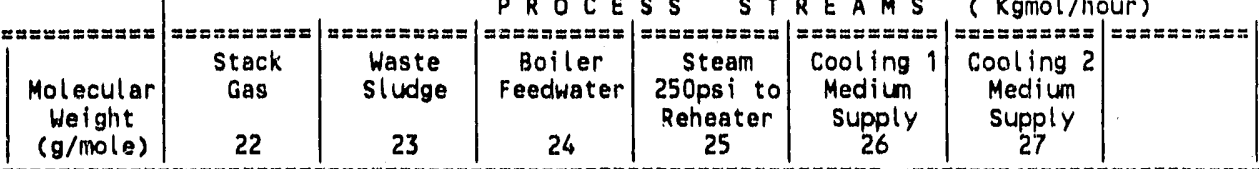

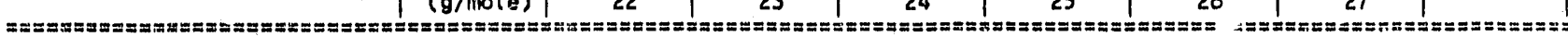
C6 $\mathrm{H} 10$ 05

sulfur

C7 H14 O7

Fe

Sio2

Al2 03

Fe2 03

$\mathrm{CaO}$

K2 0

MgO

NH3

B2 03

$\mathrm{Na} 2 \mathrm{O}$

Al2 03 si 02

Mg Si 03

(C2 H4) $x$

(C8 48$) x$

it thium

Mercury

Graphite

CH4

CO

$\mathrm{CO} 2$

H2

02

N2

म2ठ

HZS

LIOH

NO

Total, (kgmoles/hour) ......

Total, ( $\mathrm{kg} /$ hour)

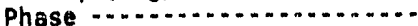

Temperature $(K) \quad \ldots . . . . . .$.

Pressure (atm) $=z= \pm=z=m=z$

256.0

210.

55.8

60.1

101.9

159.6

56.1

94.2

40.3

17.0

69.6

62.0

162.0

100.6

28.0

104.0

6.9

200.6

12.0

16.0

28.0

46.0

2.0

32.0

28.0

18.0

34.1

23.9

30.0

119.714

191.314

1008.62

162.247

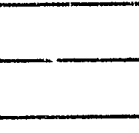

$m z=2=z==2=$
1481.895

62567.43

V

0.98
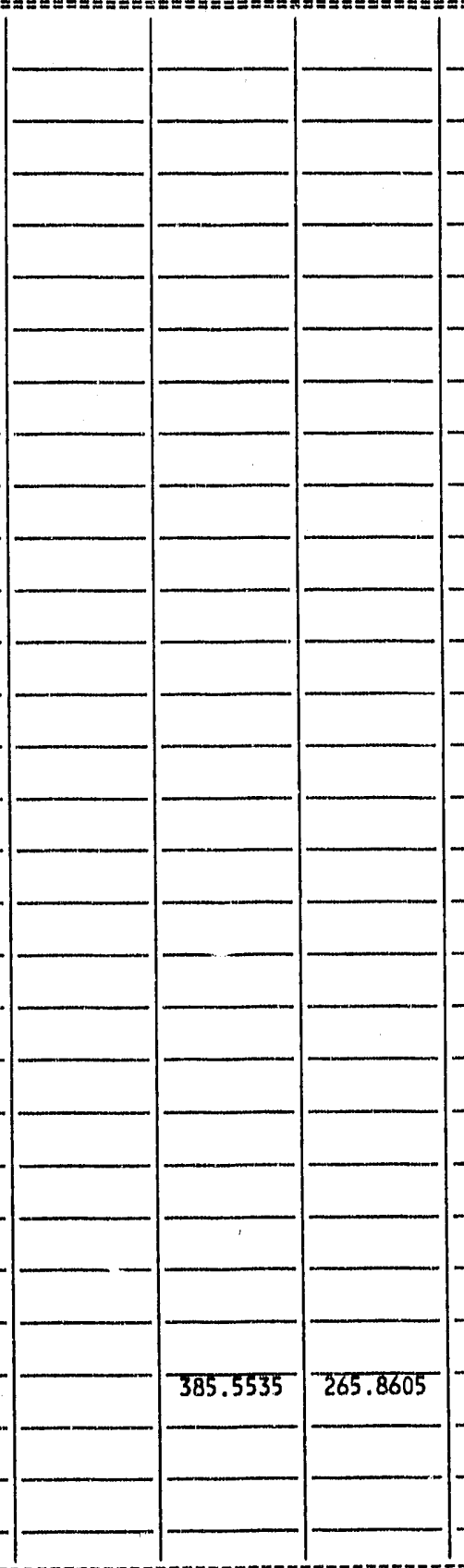
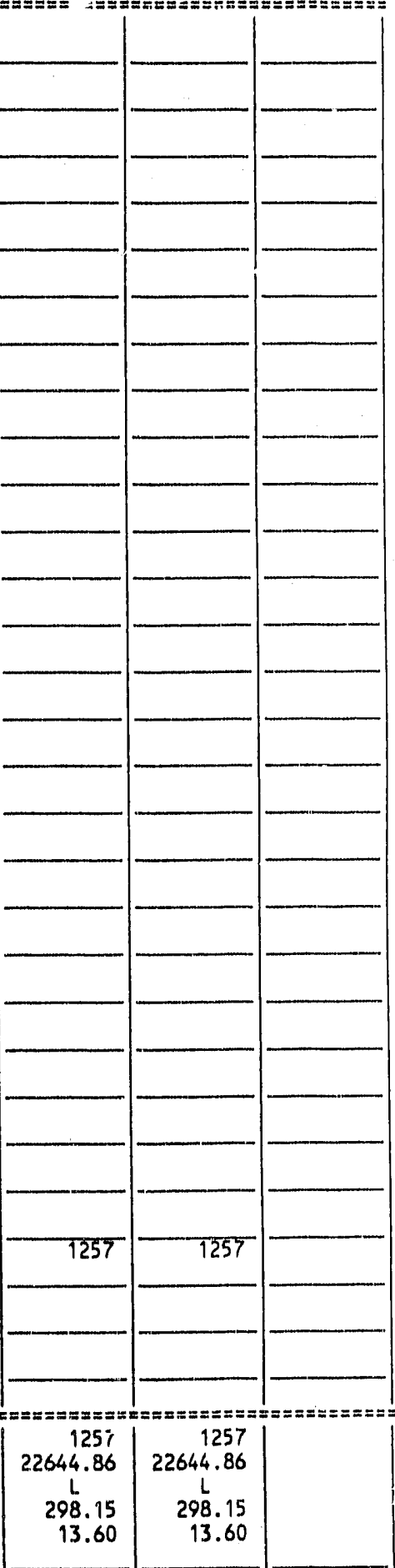


\section{Appendix B}

Summary of Energy Balance Calculations

B-1 



\section{HEAT BALANCE SUMMARY}

FOR MAIN PLASMA CHAMBER FOR WASTE

STREAM 1, (DATUM $25^{\circ} \mathrm{C}$ )

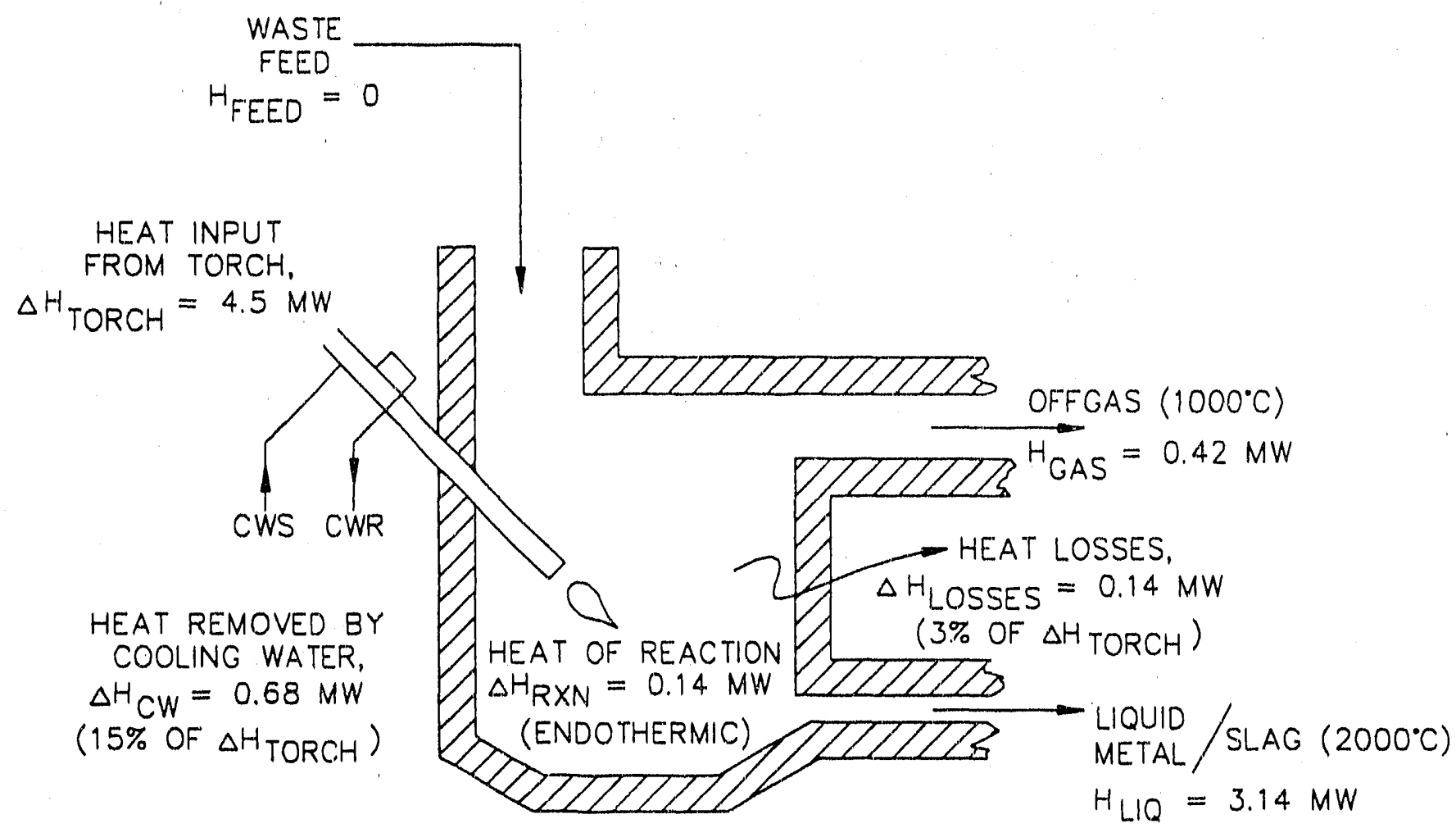

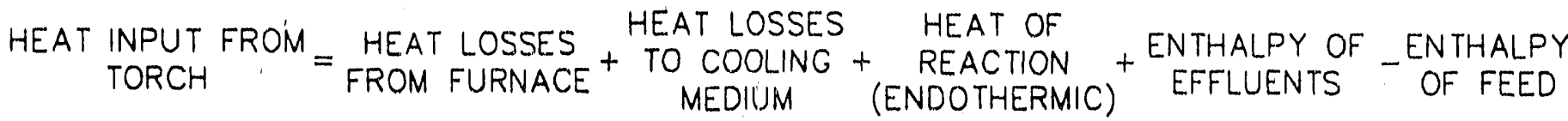




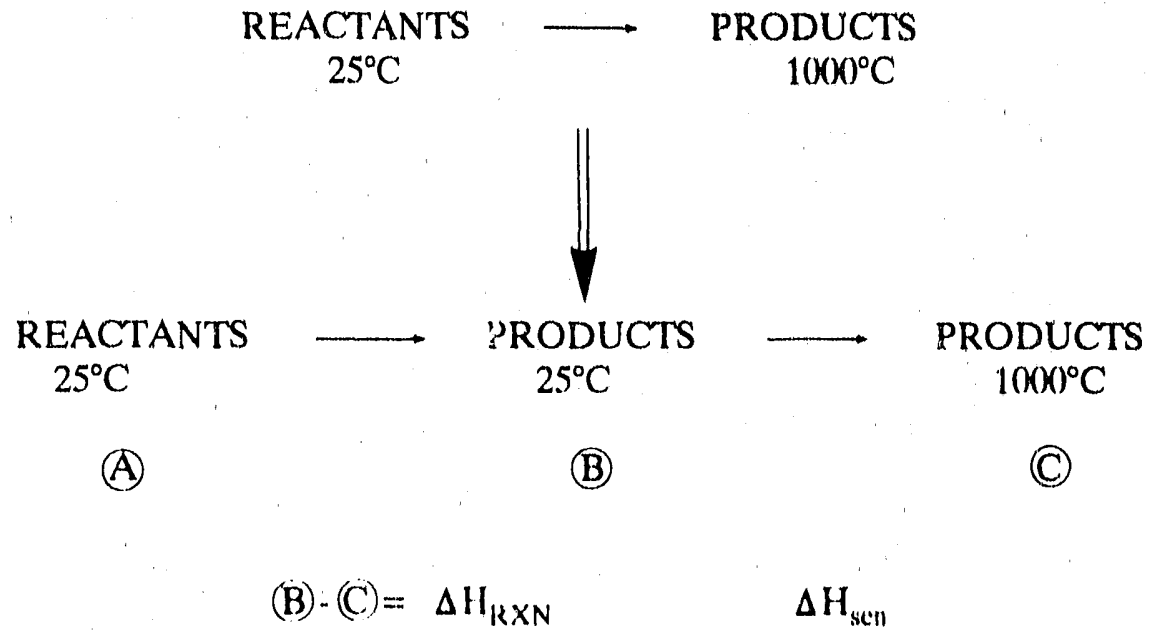

The following tables were generated to solve the energy balance. 
HEAT BALANCE SUMMARY

FOR MAIN PLASMA CHAMBER FOR WASTE

STREAM 2, (DATUM 25०

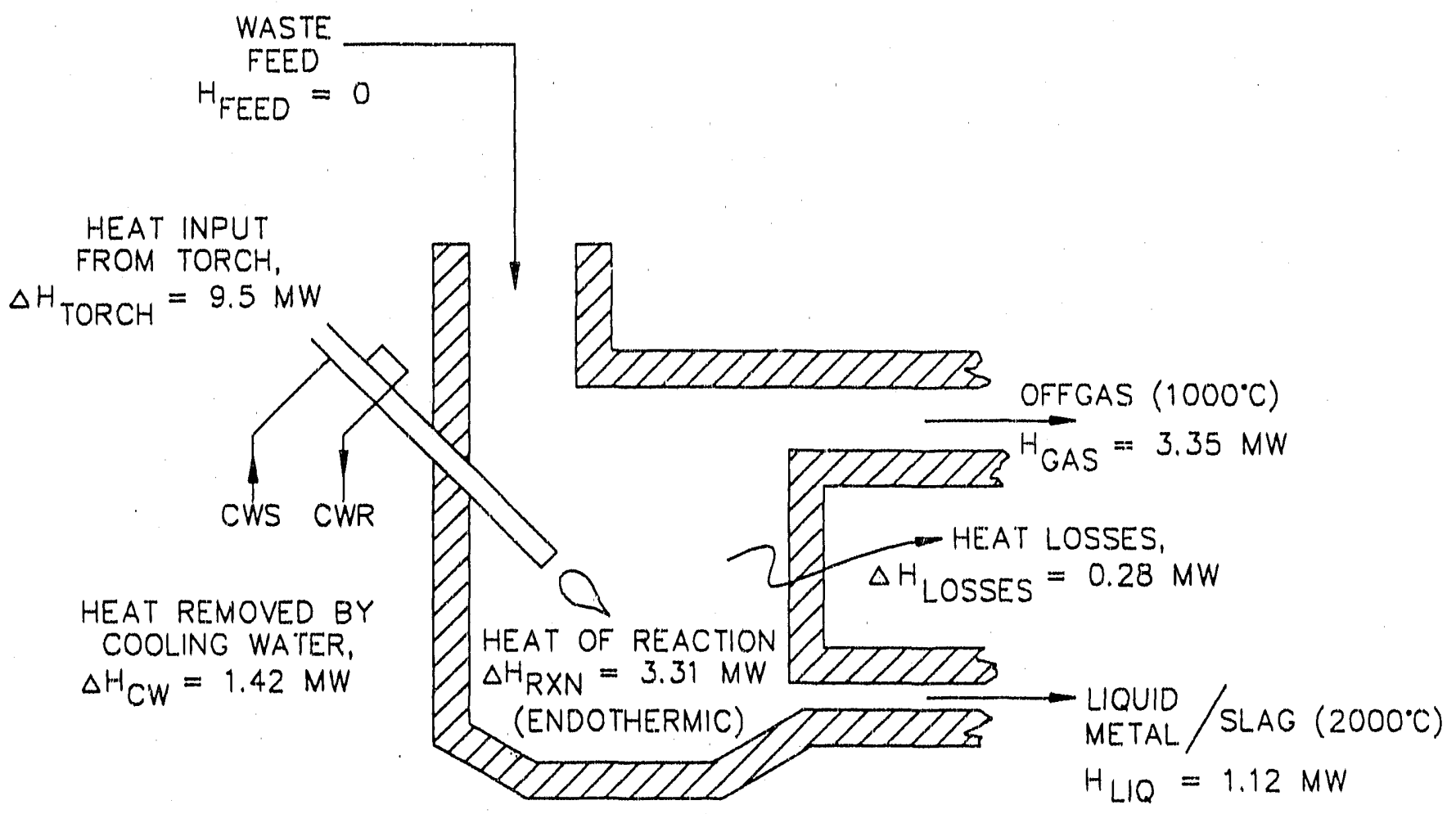




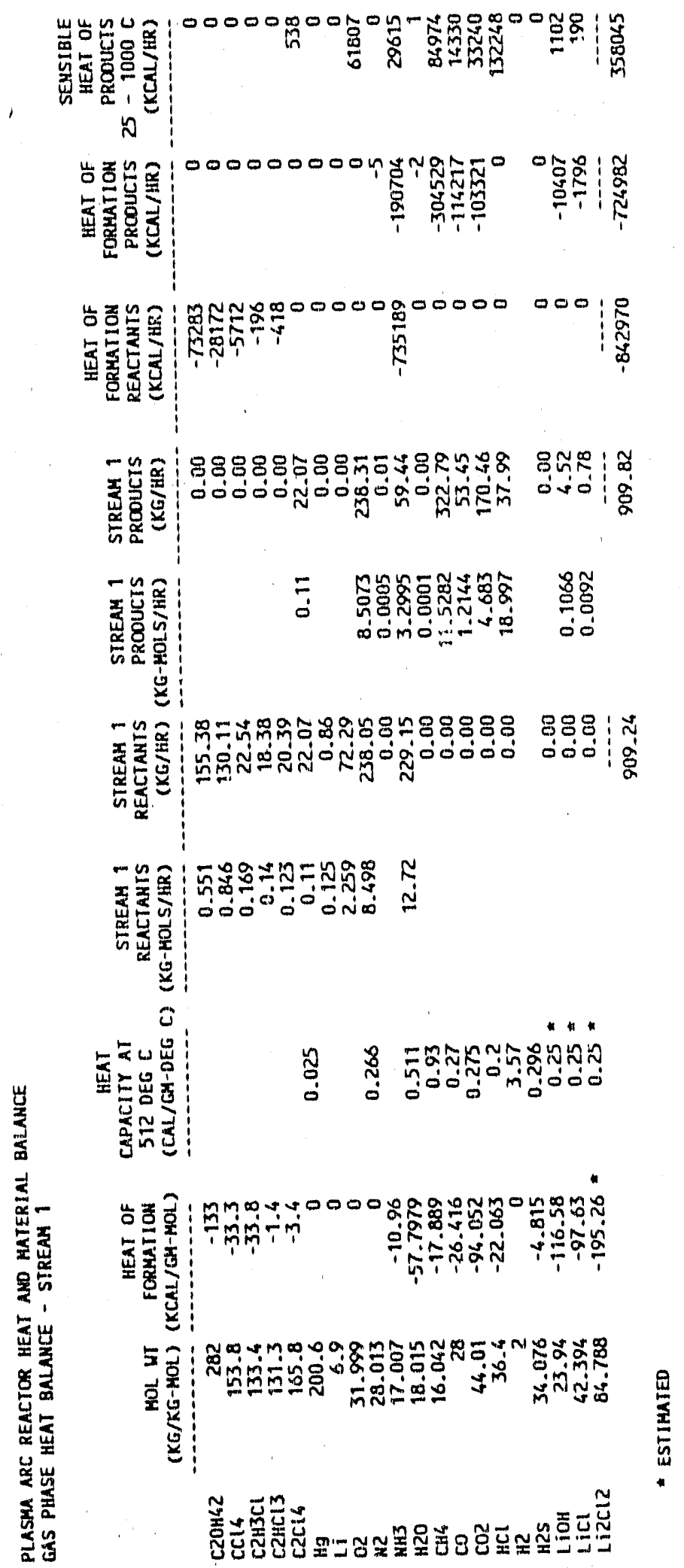

B- 6 


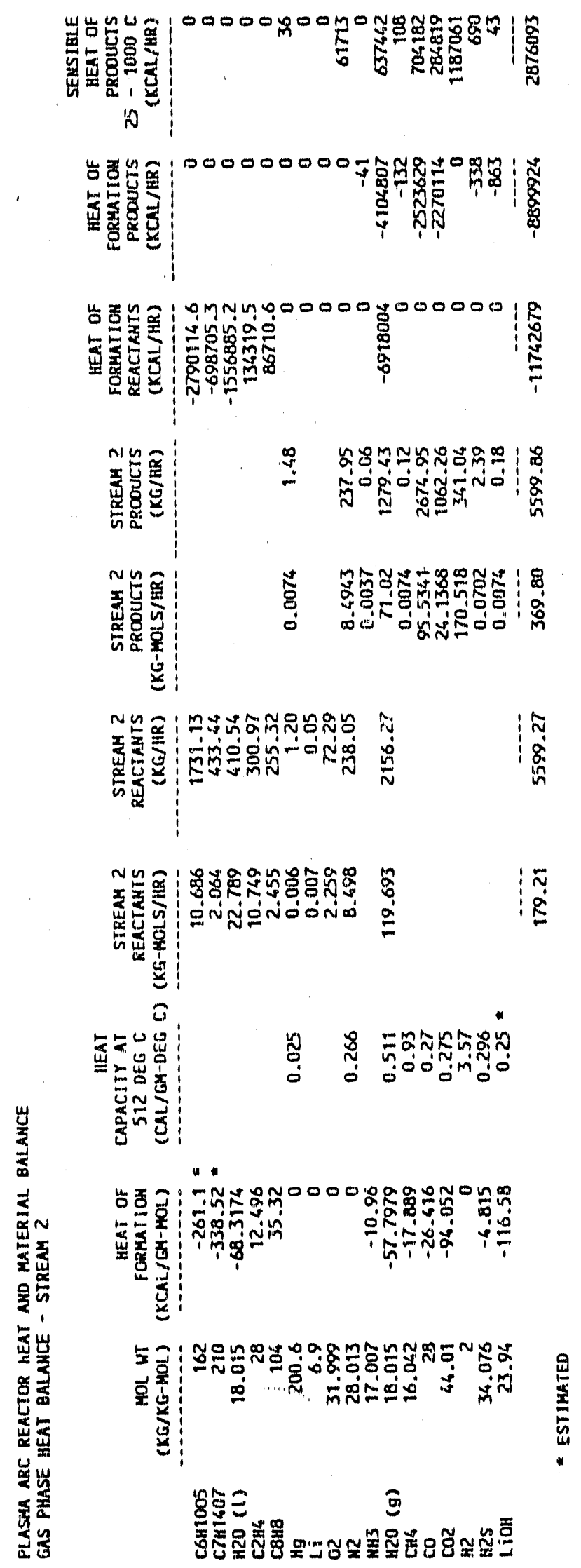

B. 7 

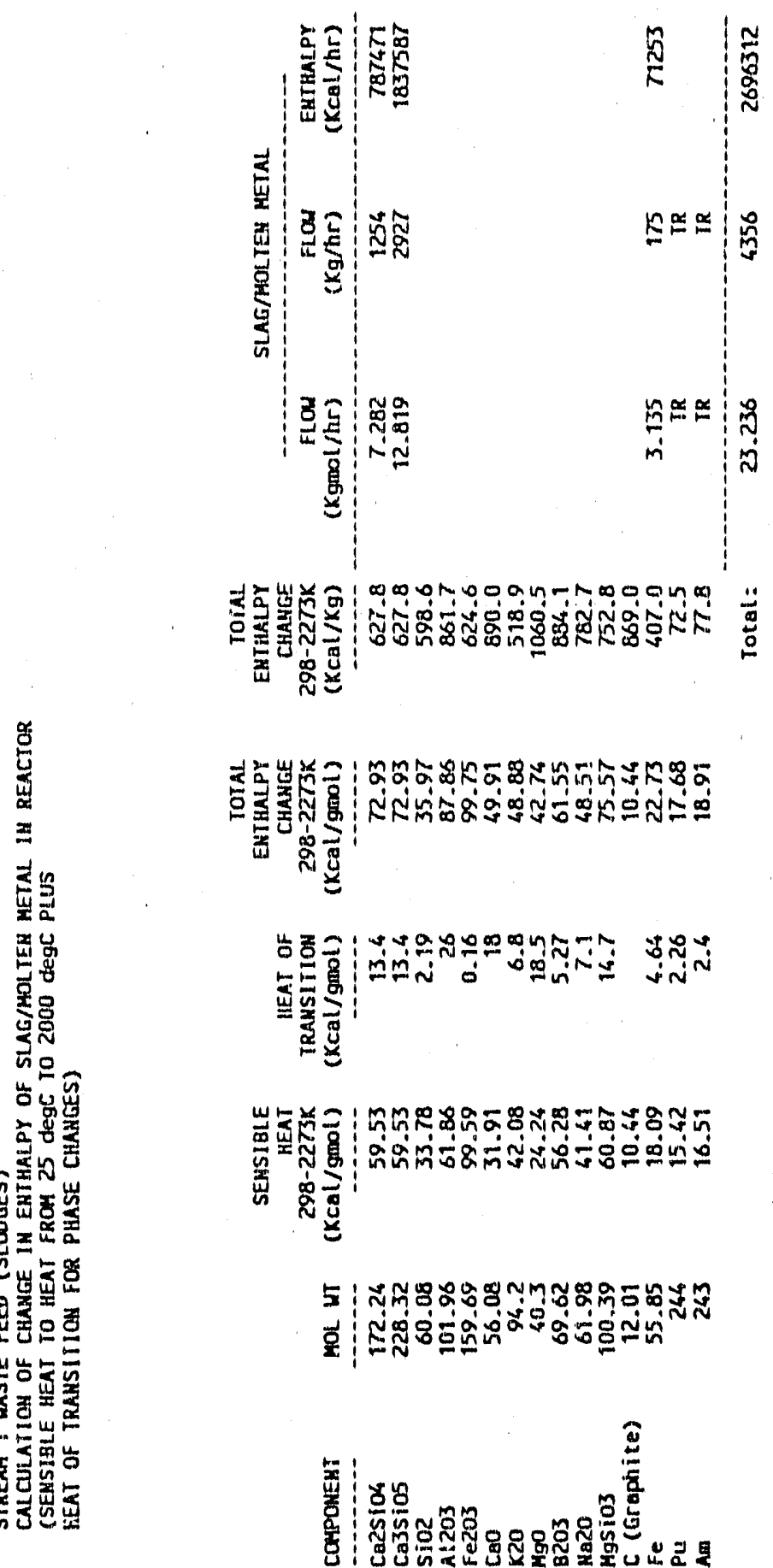

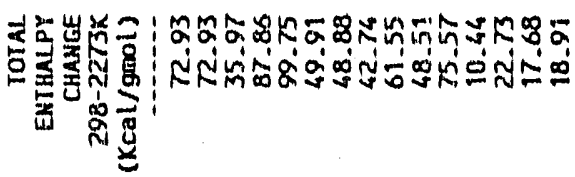

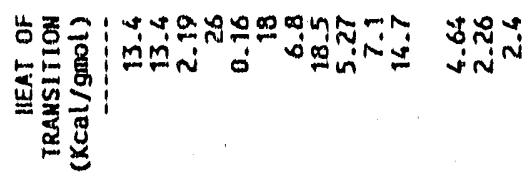

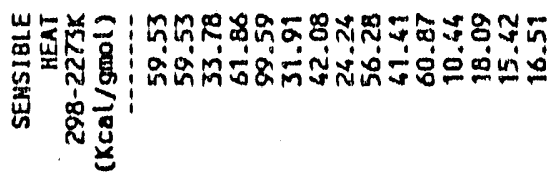

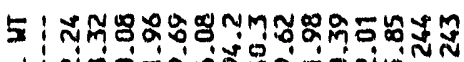

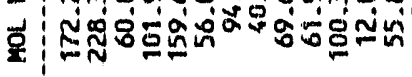

$$
\begin{aligned}
& \text { 要: }
\end{aligned}
$$



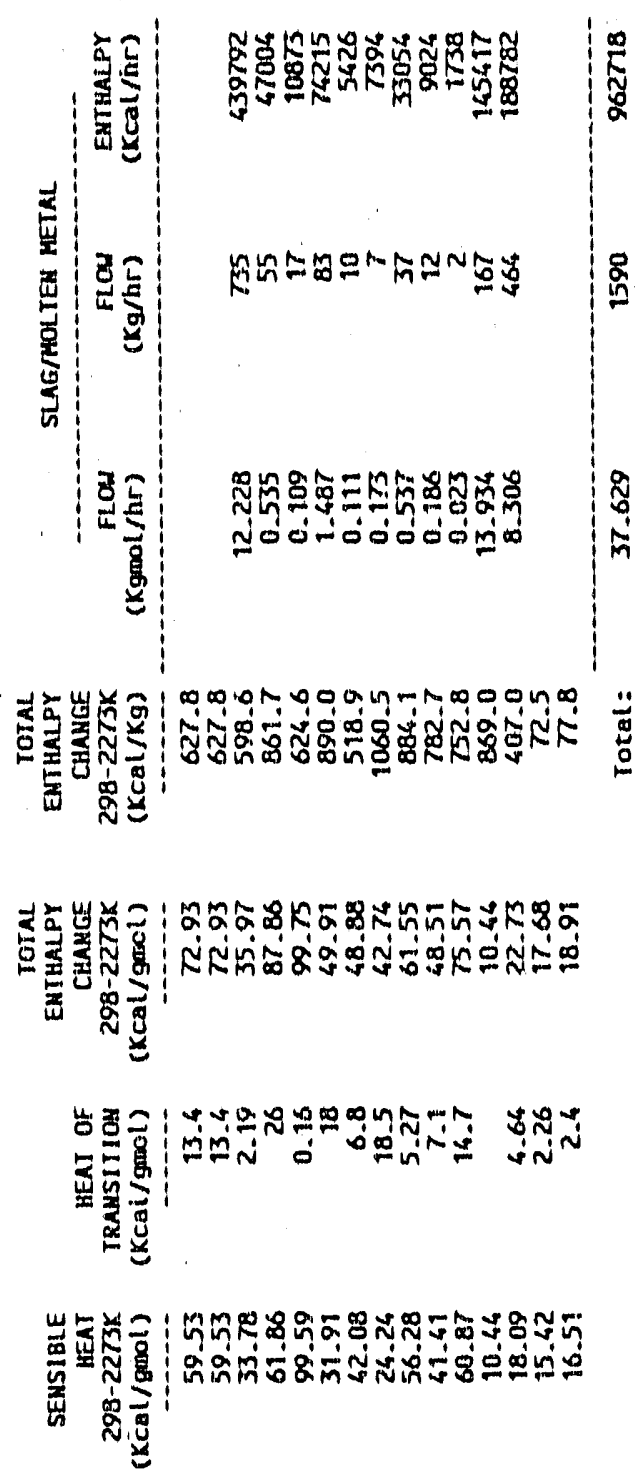

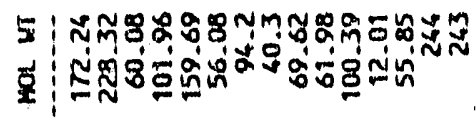

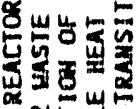

番闪

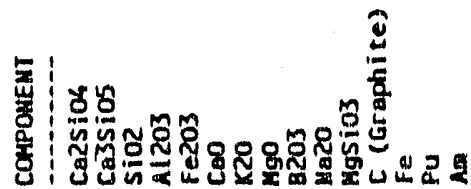


Appendix C

\section{Cost Estimate}

C-1 


\section{INTEROFFICE CORRESPONDENCE}

Date: December 20, 1990

To: K. E. Sherick, MS 3422

From:

A. R. Millward, MS $3508 / \mathrm{APM}$

Subject: STUDY ESTIMATE FOR THE PLASMA PYROLYSIS PROCESS - ARM-54-90

Cost Estimating has prepared the attached Study Cost Estimate. Attached are the cost estimate summary sheet, detafled cost estimate sheets, and a blank escalation sheet. As you requested, the costs identified in the estimate are based on December 1990 dollars. The blank escalation sheet is attached for your use if escalation is required.

The major assumptions and work scope which was not identified on your Flow Diagram but was included in our estimate is as follows:

The butlding that will house the Plasma Pyrolysis Process is existing or will be included in some other cost estimate. This bullding will have heating and ventilation equipment sized to handle the process, crane (if required), offices, rest rooms, lunch room, conference rooms, water and sewer, fire systems plus all butlding containment and alarm systems for radiation and contamination control, etc., necessary to handle this operation. It is assumed that the majority of the NEPA/Environmental documentation will be included in this building cost.

Included in our estimate is building modification for an operations control room with local and remote control devices (electrical and mechanical), and electrical power upgrades in the butlding and facility. Included are underground condutts and wire from an existing substation sized to feed 10 Megawatts of power to the bullding. Also included is power distribution equipment to handle the 10 Megawatts of power at the building. The upgrade of the facility power does not include upgrading of the power to the facility, modifications to the substations at the factlity, or at the Scoville Substation.

Included in the Engineering Cost is extra time to perform studies of the possible emissions that could be emitted by the process. This is a major cost and is included with the assumption that this might have to be done prior to the building or facility NEPA documentation. 
K. E. Shertck

December 2.0, 1990

ARM- $54-90$

Page 2

Attached is a detalled cost estlmate sheet and a summary sheet labeled

"Appendix A". These sheets are included to identffy estimated costs of a pretreatment auger/shredder which can be added to the total estimated cost identiffed in the other attached cost estimate sheets if required.

If we can be of further assistance, please feel free to call me at 526-0944.

arm

Attachments:

As Stated

cc: Central Flles, MS 1651

Project File \#5147 \$1/20?

A. R. MHllward Fłle 
EGaG Idaho, Inc.

COST ESTIMATE SUMMARY

Type of Estimate : STUDY

File No.: 5147

Date:

$12 / 20 / 90$

Project : PLASMA PYROLYSIS PROCESS

Prepared BY: A. R. Millward

Checked/Approved By:

20

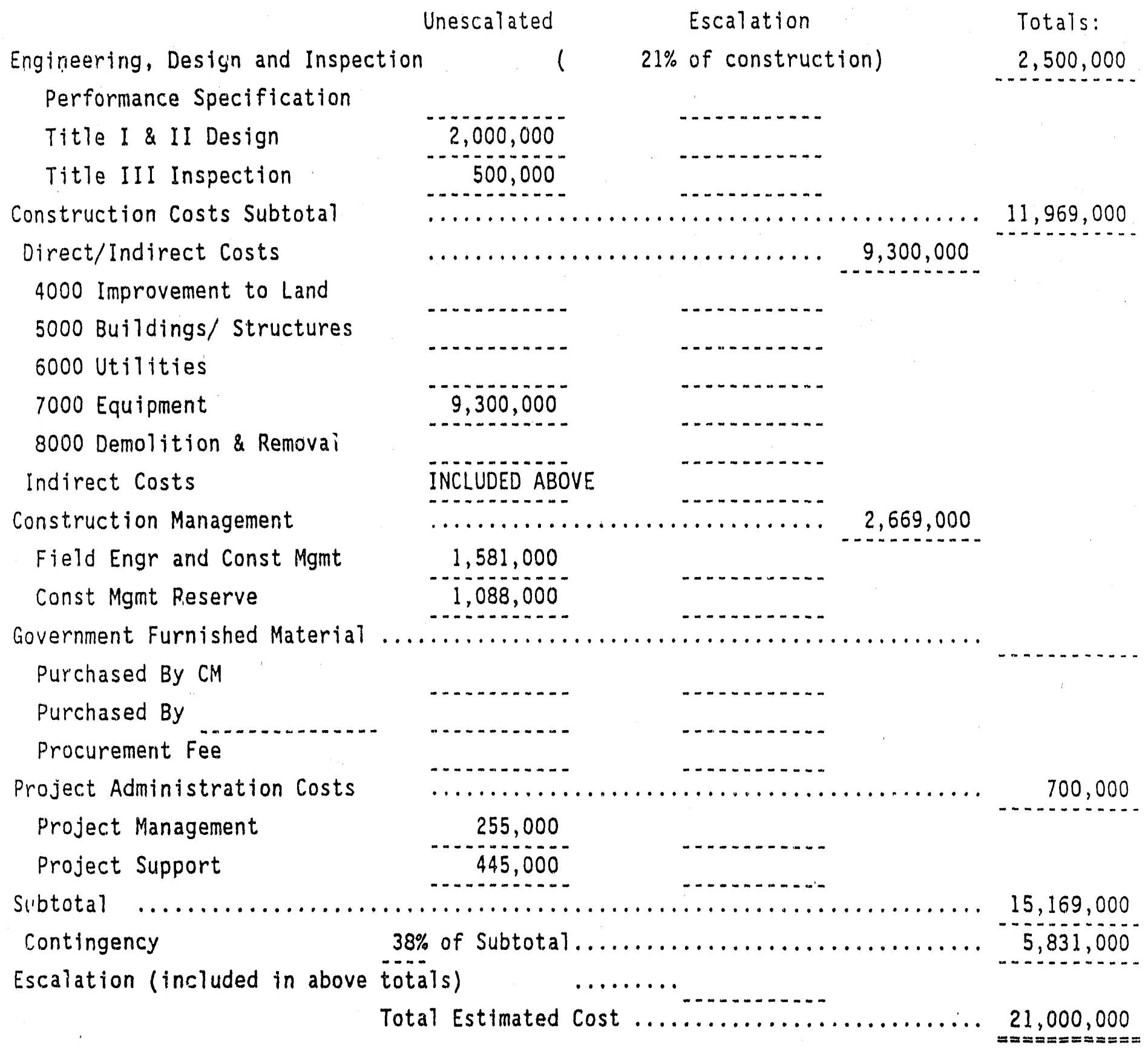

Comments : 


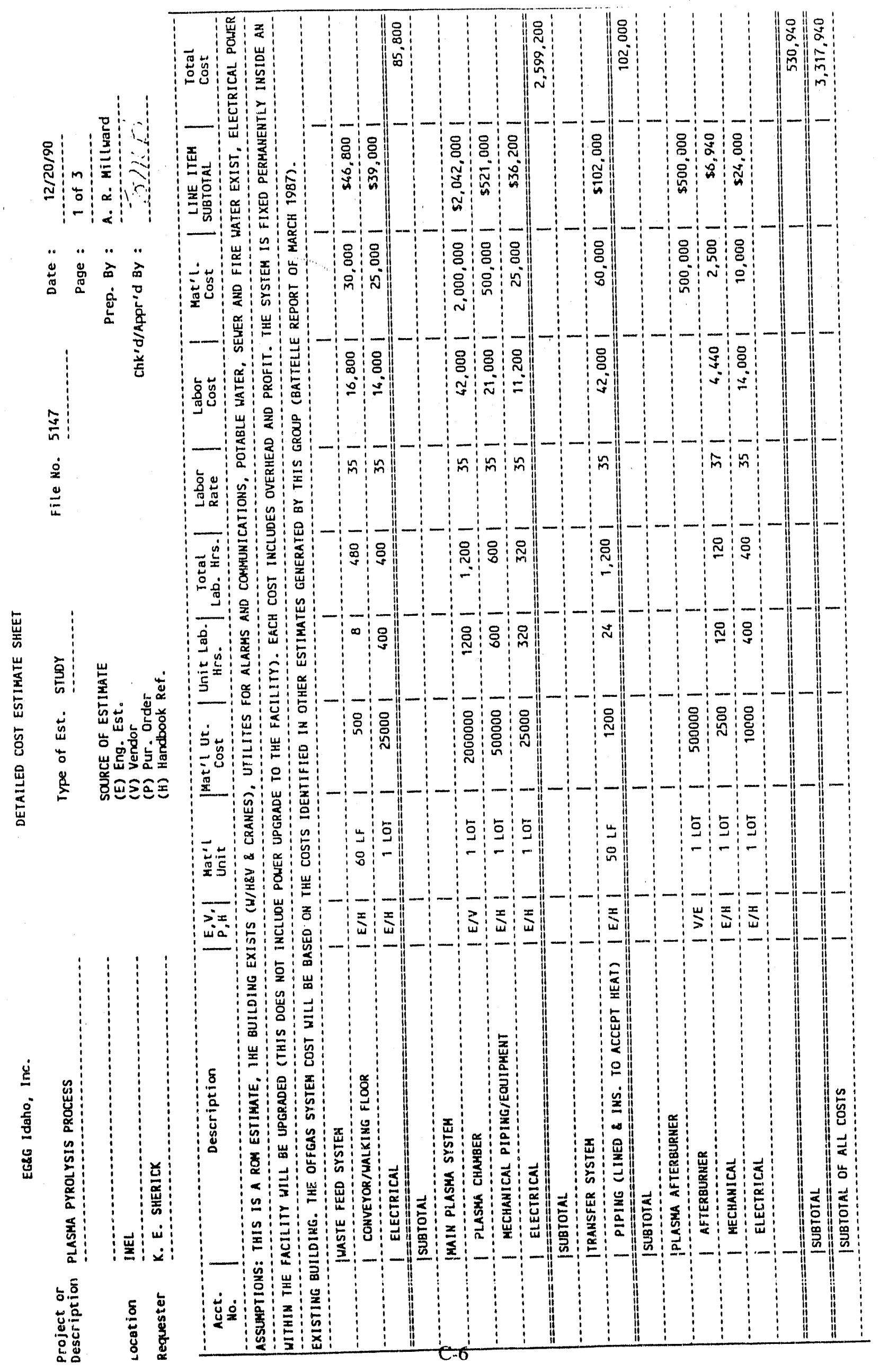




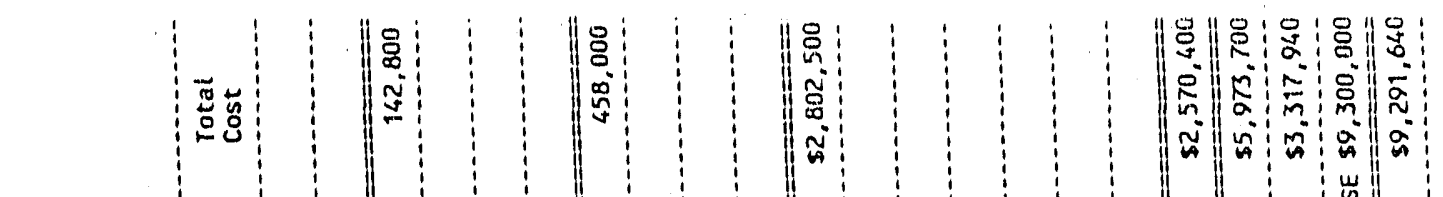

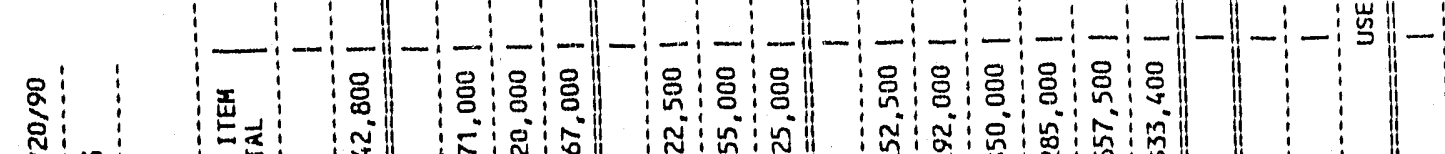
勇的 崖

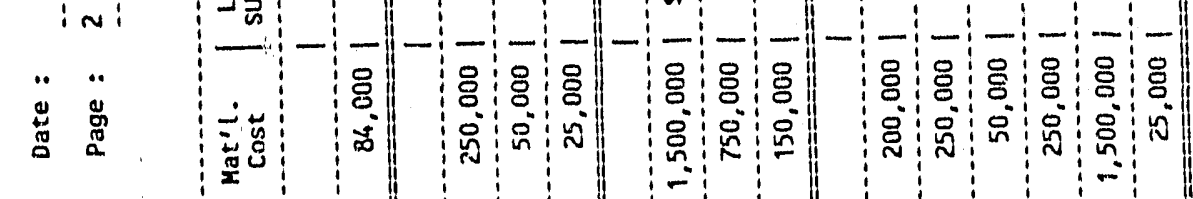

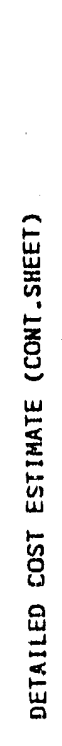

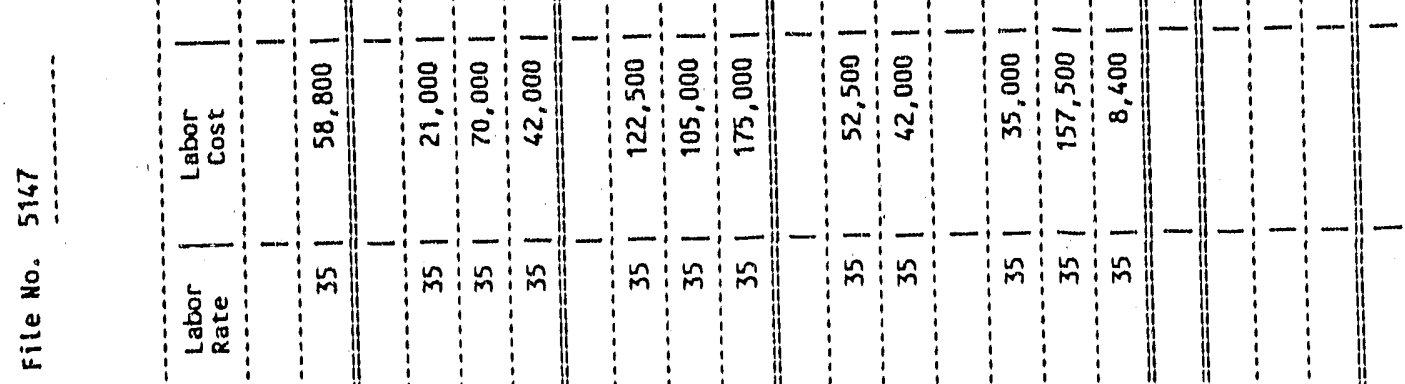

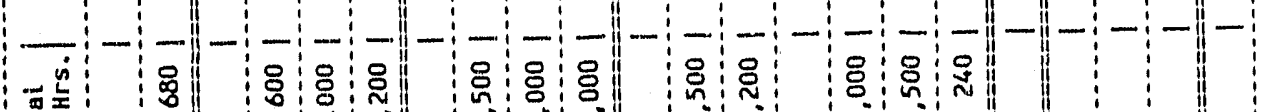
总 -

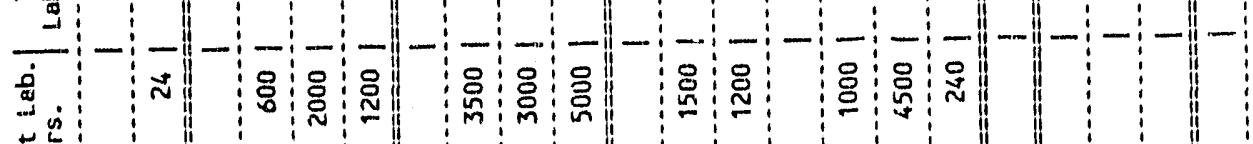
衰

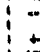

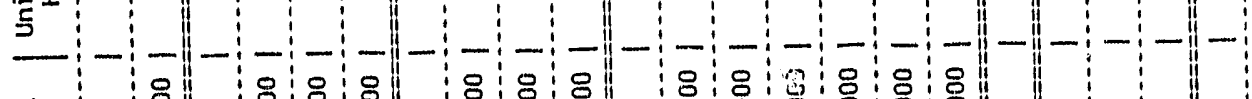

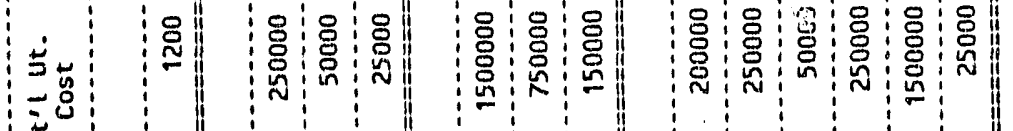
西

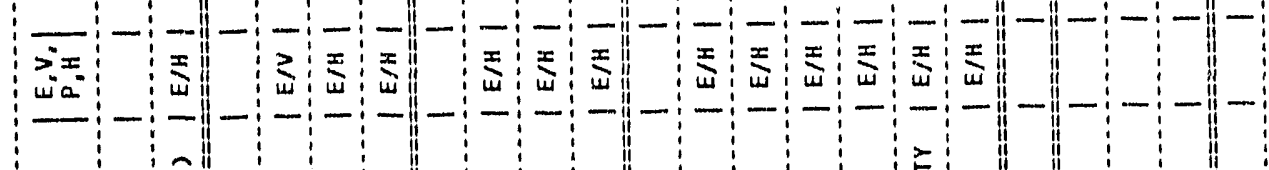

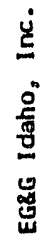

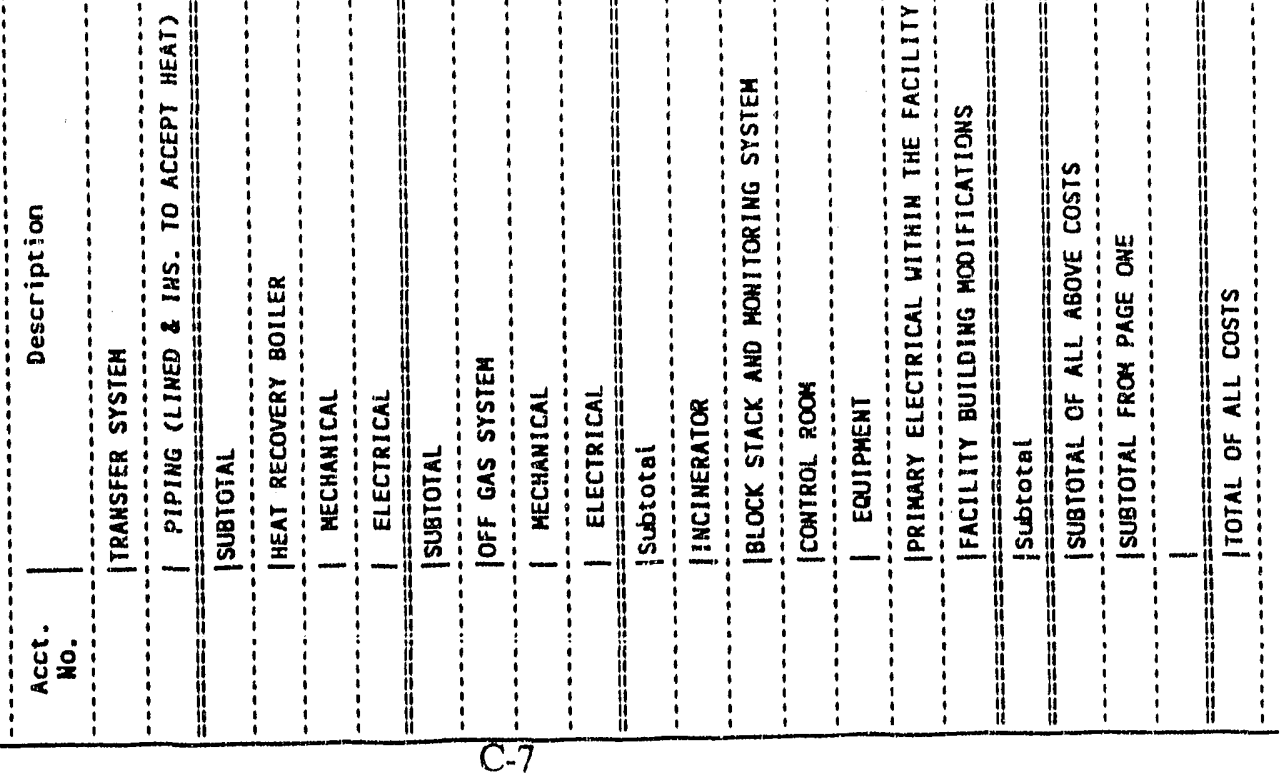




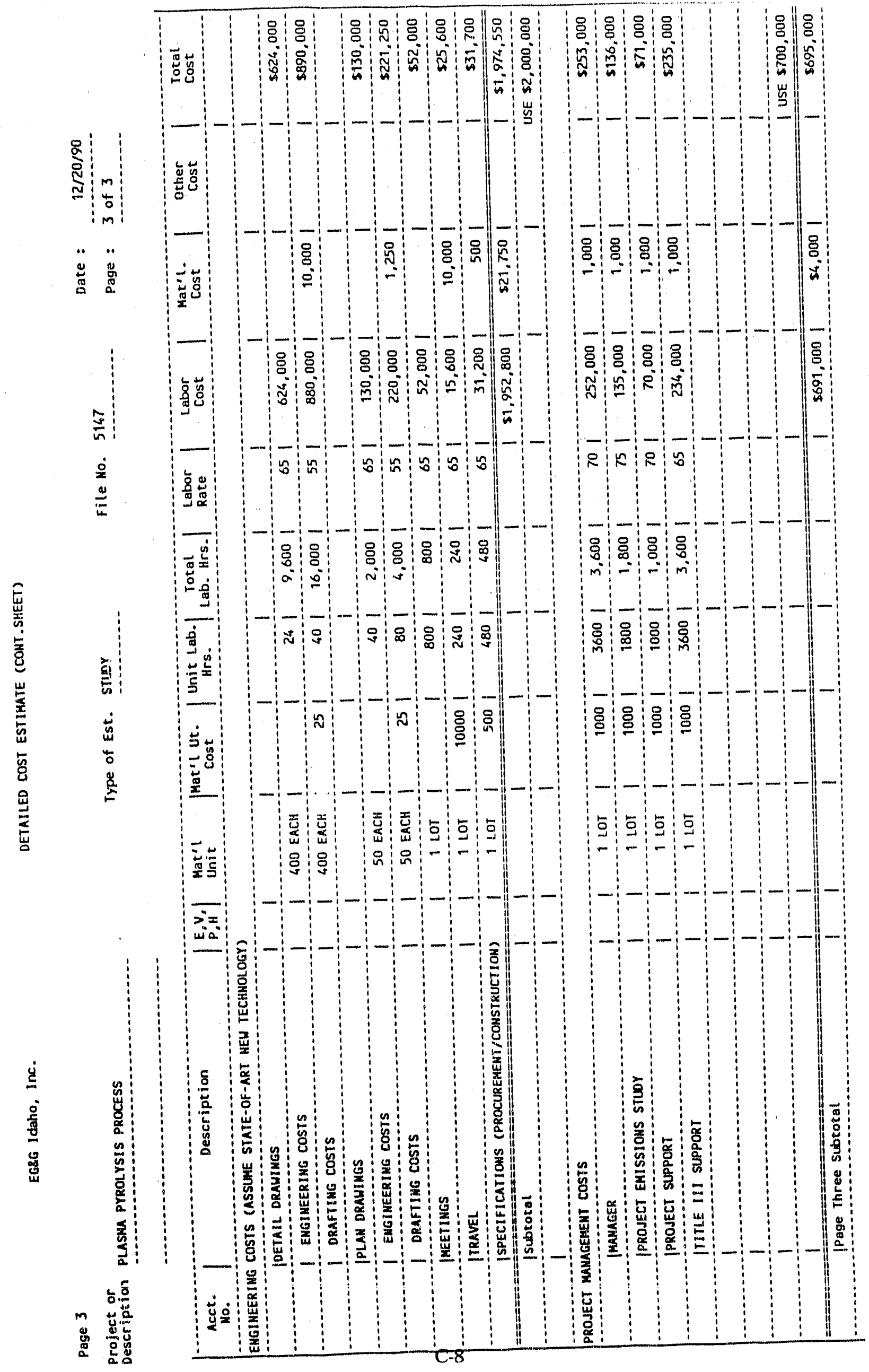


EG\&G Idaho, Inc.

Type of Estimate : STUDY

File No.: 5147

Date: $\quad 12 / 20 / 90$

Project : PLASMA PYROLYSIS PROCESS - APPENDIX A

Prepared By : A. R. MiTiward

Checked/Approved By:

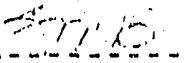

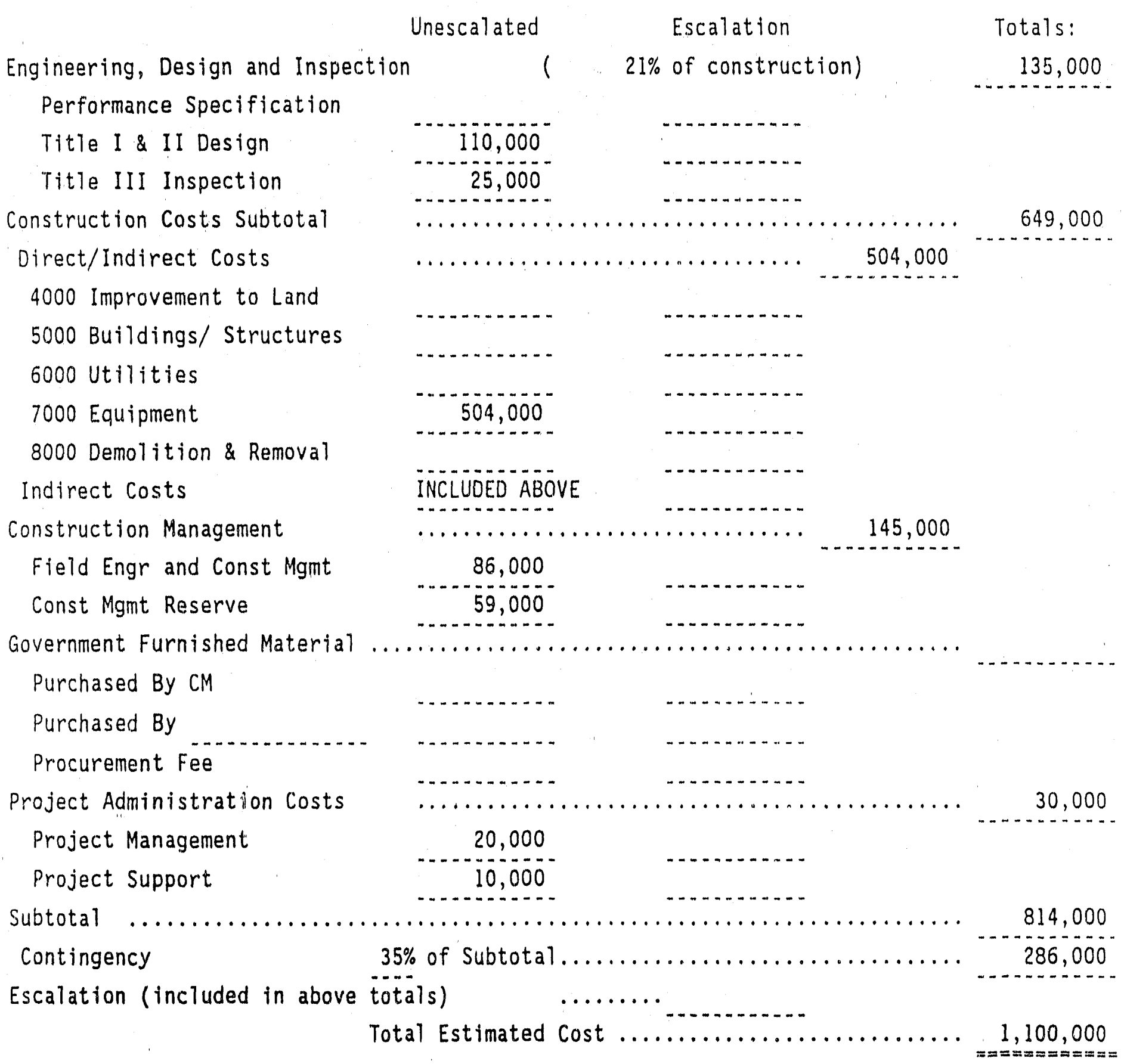

Comments: 


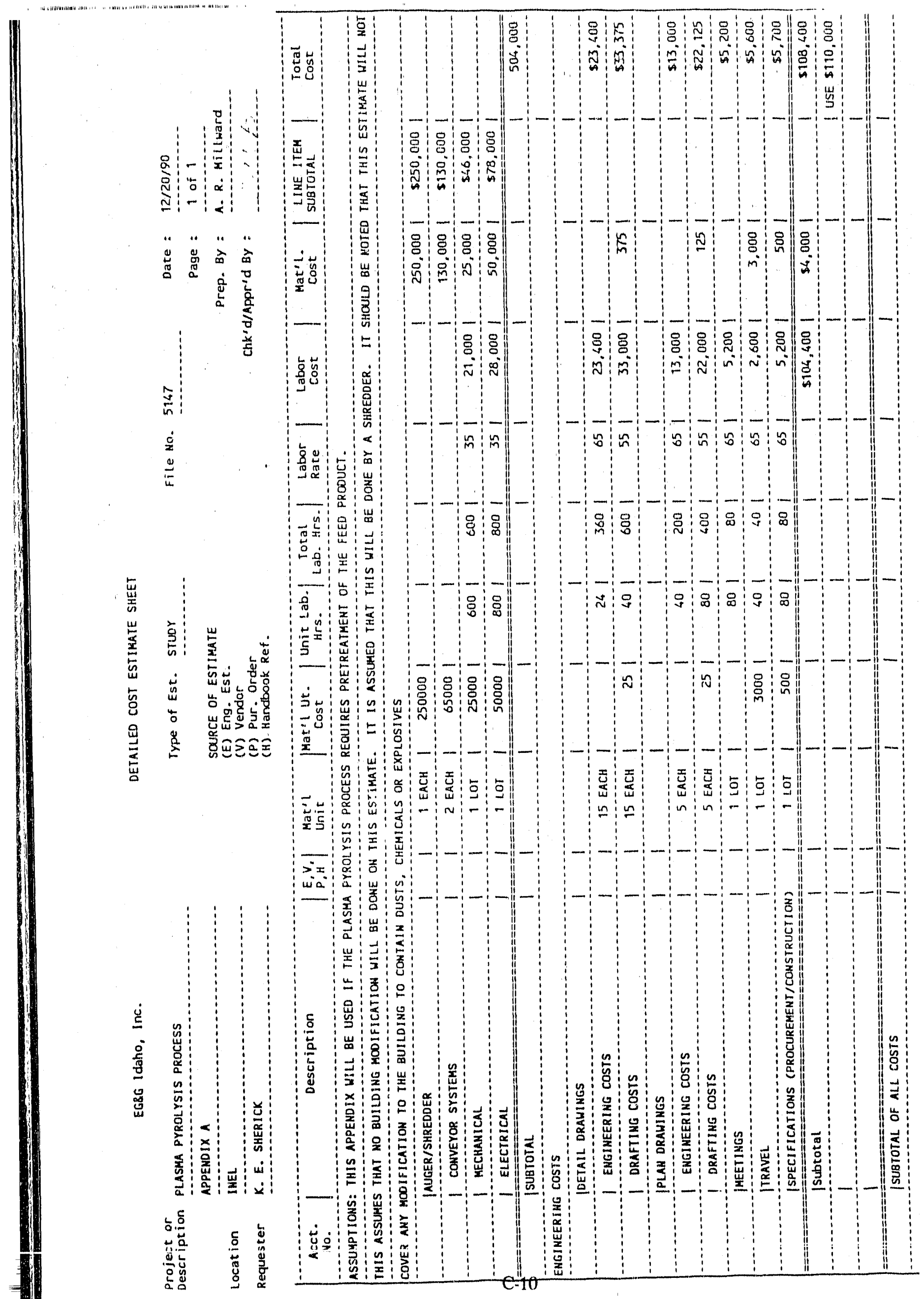




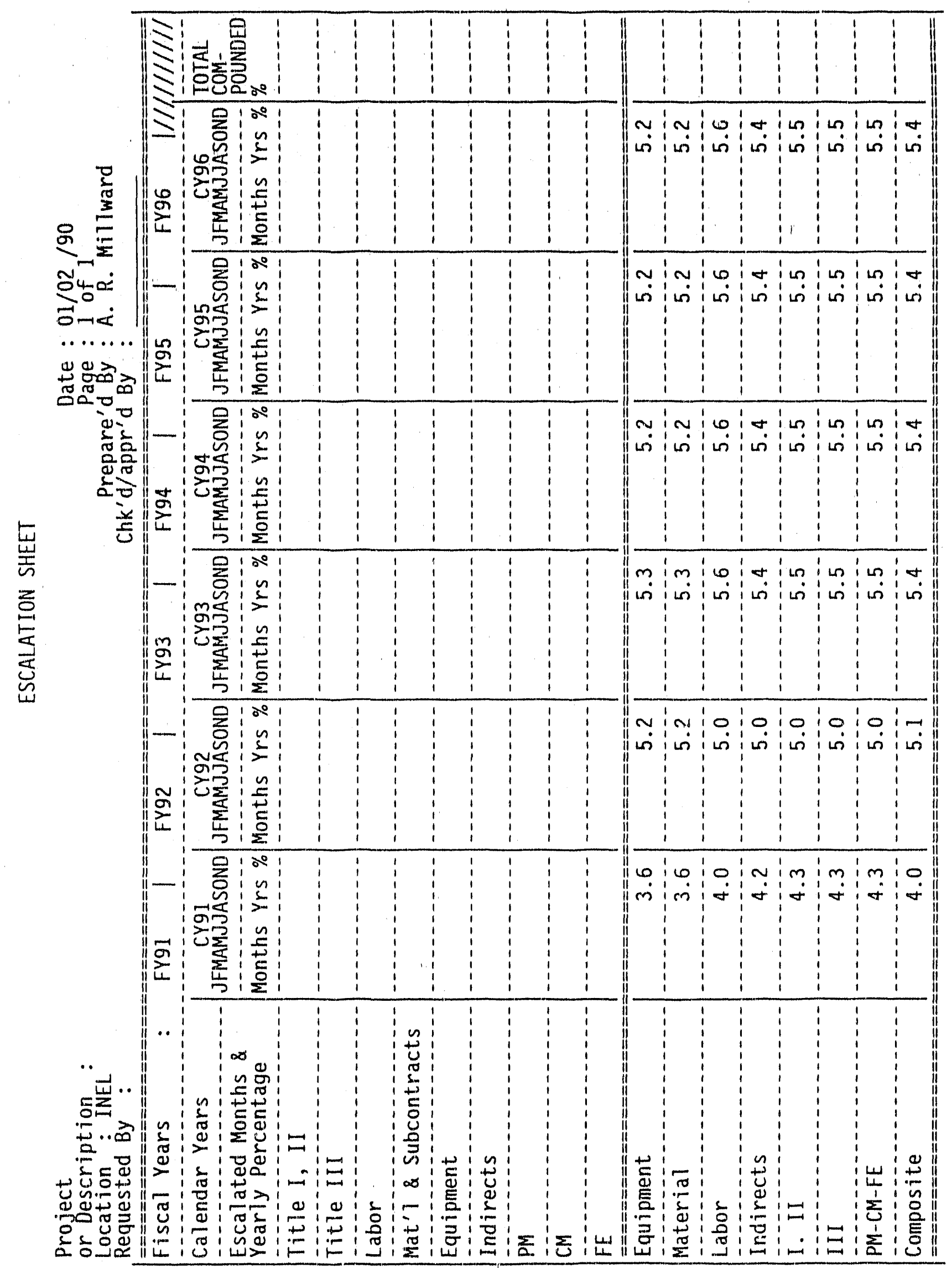

C-11 
Appendix D

\section{Discussion of Calculation Methods}

D-1 


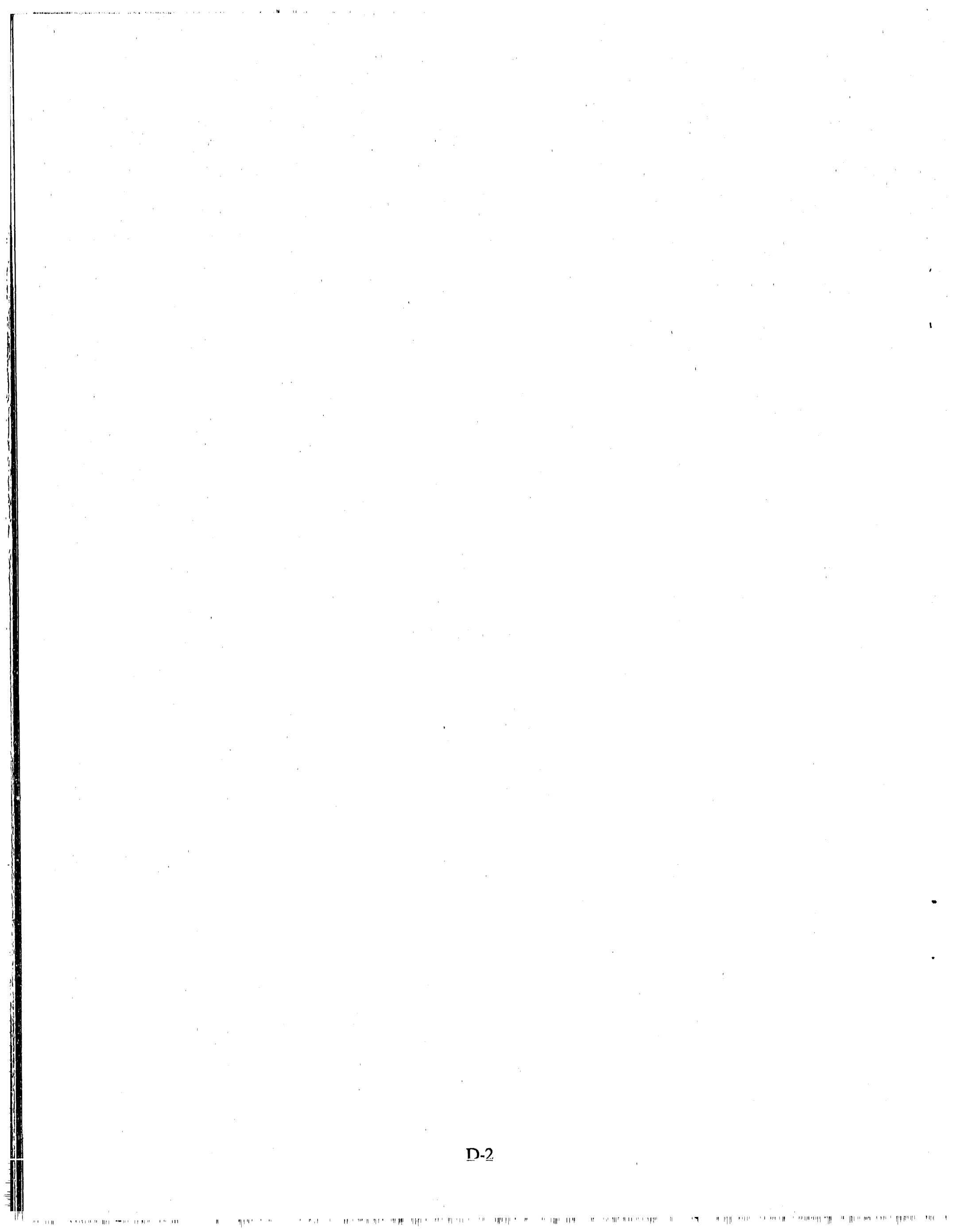




\section{Discussion of Calculation Methods}

The heat and material balances prepared for this study are based on both manual calculations and computer simulation. Determination of partitioning of species between the vapor and liquid phases in the main plasma chamber was based on the following assumptions:

- The liquid phase in the main chamber would be maintained at $20000^{\circ} \mathrm{C}$ and that this would result in a vapor phase temperature of $10000^{\circ} \mathrm{C}$

- All hydrocarbon, chlorinated hydrocarbon, and metal species with a vapor pressure greater than one atmosphere at $2000^{\circ} \mathrm{C}$ would be in the vapor phase (this included lithium and mercury)

- All mineral and metal species with vapor pressure lower than one atmosphere at $2000^{\circ} \mathrm{C}$ would be in the liquid phase

- One mole of steam per mole of carbon atoms is added at the main plasma chamber to minimize carbon (soot) formation

- Air is used as the plasma gas

- $\quad$ No chemical reaction occurs between vapor and liquid species

- There is no entrainment of liquid or solid phases into the vapor phase.

Vapor phase chemical equilibrium at $1\left(100^{\circ} \mathrm{C}\right.$ and one atmosphere was calculated for the vapor species determined as described above using the NASA Lewis chemical equilibrium computer program, CEC76. This program determines chemical equilibrium based on a free-energy minimization technique when two thermodynamic states are defined. The program is described in detail in NASA document SP-273, Computer Program for Calculation of Complex Chemical Equilibrium Compositions, Rocket Performance, Incident and Reflected Shocks, and Chapman-Jouguet Detonations. ${ }^{14}$

An overall heat balance was calculated manually for the main plasma chamber. The heat of the pyrolysis reactions were determined from heats of formation(s) found in Perry's Chemical Engineers' Handbook ${ }^{9}$ and in the CRC Handbook of Chemistry and Physics. ${ }^{10}$ Sensible heat of the effluent vapor and liquid were determined from molar average heat capacity of each stream. Heat capacity for each molecular species as a function of temperature were found in the same references. The power input of the torch was determined from the heat balance based on the assumptions given above. 
The plasma olf-gas is then assumed to be heated to approximately $1370^{\circ} \mathrm{C}$ in a plasma torchheated afterburner to ensure destruction of hazardous organic species in the off-gas. The afterburner temperature of $1370^{\circ} \mathrm{C}$ was selected as the highest practical temperalure for which conventional refractories would be suitable. The CEC76 program was also used to determine the equilibrium composition of the afterburner off-gas. A heat balance was calculated for the afterburner in the same manner as the main chamber to determine the power input of the afterburner plasma torch.

An off-gas treatment system model previously developed for simulating in situ vitrification off-gas treatment was used to simulate the off-gas treatment material and energy balances for this study. This model was developed using ASPEN/SP, a commercial chemical process simulator avallable from Simulation Sciences Inc. The off-gas treatment unit operations simulated with ASPEN/SP included heat exchange, absorption, compression, mixing, and vapor/liquid flashing. ASPEN/SP has capability to use several equations of state to determine thermodynamic properties and vapor/liquid equilibrium. The Redlich-Kwong equation of state was used for the simulations performed for this study. Absorption of acid gases in the quench tower and scrubber, lee, hydrochloric acid, were simulated using a Henry's Law model.

The treated eflluent from the off-gas treatment will contain carbon monoxide which must be oxidized to carbon dioxide prior to being vented to the atmosphere. The heat balance and effluent composition of the off-gas incinerator were determined using the NASA CEC76 program described above. 


